\title{
Pathophysiology of Parkinsonism
}

\author{
Adriana Galvan and Thomas Wichmann \\ Department of Neurology, School of Medicine, and Division of Sensorimotor Systems, Yerkes \\ National Primate Center, Emory University, Atlanta GA
}

\begin{abstract}
The motor signs of Parkinson's disease are thought to result in large part from reduction of dopamine in the basal ganglia. Over the last few years, many of the functional and anatomical consequences of dopamine loss in these structures have been identified, both in the basal ganglia and in related areas in thalamus and cortex. This knowledge has contributed significantly to our understanding of the link between degeneration of dopamine neurons in the midbrain, and the development of parkinsonism. This review discusses the evidence that implicates electrophysiologic changes (including altered discharge rates, increased incidence of burst firing, interneuronal synchrony, oscillatory activity, and altered sensorimotor processing) in basal ganglia, thalamus, and cortex, in parkinsonism. From these studies, parkinsonism emerges as a complex network disorder, in which abnormal activity in groups of neurons in the basal ganglia strongly affect the excitability, oscillatory activity, synchrony and sensory responses of areas of the cerebral cortex that are involved in the planning and execution of movement, as well as in executive, limbic or sensory functions. Detailed knowledge of these changes will help us to develop more effective and specific symptomatic treatments for patients with Parkinson's disease.
\end{abstract}

\section{Keywords}

Parkinson's disease; parkinsonism; basal ganglia; dopamine; GABA; glutamate; putamen; globus pallidus; subthalamic nucleus; substantia nigra; bursts; oscillations

\section{Introduction}

The term 'Parkinson's disease' refers to a group of neurodegenerative conditions that affect several regions of the brain, including the pigmented nuclei in midbrain and brainstem, the olfactory tubercle, the cerebral cortex, and elements of the peripheral nervous system (e.g., Braak et al., 2006). The earliest and most striking physical disabilities resulting from these changes are motor impairments that, together, are called 'parkinsonism'. These include paucity and slowness of movement (akinesia, bradykinesia), muscle stiffness (rigidity), and tremor at rest. In large part, these problems result from the prominent degeneration of dopaminergic neurons in the midbrain, and the consequent deficiency of dopamine in brain areas that receive dopaminergic inputs from those neurons, specifically the post-commissural putamen and other basal ganglia regions. This review highlights some of the physiologic, anatomical and biochemical consequences of dopamine loss in the basal ganglia, which may be responsible

Address for Correspondence: Thomas Wichmann, MD, Yerkes National Primate Research Center, 954 Gatewood Road, NE, Atlanta, GA 30329, Phone: 404-727-3511, FAX: 404-727-9294, Email: twichma@emory.edu.

Publisher's Disclaimer: This is a PDF file of an unedited manuscript that has been accepted for publication. As a service to our customers we are providing this early version of the manuscript. The manuscript will undergo copyediting, typesetting, and review of the resulting proof before it is published in its final citable form. Please note that during the production process errors may be discovered which could affect the content, and all legal disclaimers that apply to the journal pertain. 
for the emergence of parkinsonism. The study of these changes has been greatly facilitated by the availability of toxins with which highly selective dopamine loss can be induced in animals, including 1-methyl-4-phenyl-1,2,3,6-tetrahydropyridine (MPTP) in monkeys and mice (Burns et al., 1983, Forno et al., 1993, Langston et al., 1983), and 6-hydroxydopamine (6-OHDA) in rats and other animals (Simola et al., 2007, Ungerstedt, 1968, Ungerstedt and Arbuthnott, 1970).

\section{Circuit anatomy of the basal ganglia}

Parkinsonism is considered to result primarily from abnormalities of basal ganglia function. The basal ganglia include the neostriatum (caudate nucleus and putamen), the external and internal pallidal segments (GPe, GPi), the subthalamic nucleus (STN), and the substantia nigra with its pars reticulata $(\mathrm{SNr})$ and pars compacta $(\mathrm{SNc})$. They participate in anatomically and functionally segregated loops that involve specific thalamic and cortical areas. These parallel circuits are divided into 'motor', 'associative' and 'limbic' loops, depending on the function of the cortical area involved (Alexander et al., 1986, Alexander et al., 1990, Kelly and Strick, 2004, Middleton and Strick, 2000). The thalamic components of these circuits are largely separate from those engaged by cerebellar outflow pathways (Middleton and Strick, 2000).

Striatum and STN receive glutamatergic afferents from specific areas of the cerebral cortex or thalamus, and transfer the information to the basal ganglia output nuclei, GPi and SNr. The projections between the striatum and $\mathrm{GPi} / \mathrm{SNr}$ are divided into two separate pathways, a 'direct' (monosynaptic) connection, and an 'indirect' projection, via the intercalated GPe and STN. Output from GPi/SNr goes largely to the ventral anterior and ventrolateral nuclei of the thalamus (VA/VL), which, in turn, project back to the cerebral cortex. Lesser basal ganglia projections reach the intralaminar centromedian and parafascicular thalamic nuclei (CM/Pf) and brainstem structures such as the superior colliculus, pedunculopontine nucleus (PPN), and the reticular formation.

Abnormal activity in the 'motor' loop of the basal ganglia is strongly implicated in the development of parkinsonism. This loop, depicted in figure 1 (left panel), originates in precentral motor areas, and involves the post-commissural putamen and motor regions of GPe, $\mathrm{GPi}, \mathrm{SNr}$ and STN, as well as VA/VL. CM/Pf receive collaterals of the GPi/SNr projection to VA/VL, and send efferents back to the putamen, specifically targeting the 'direct' pathway, and cholinergic striatal interneurons (Lapper and Bolam, 1992,Meredith and Wouterlood, 1990,Sidibe and Smith, 1996,Sidibe and Smith, 1999).

The striatum also receives prominent dopaminergic input, from the SNc. The nigrostriatal projection terminates predominately at the necks of dendritic spines of the striatal medium spiny output neurons (MSNs). MSN spines also receive corticostriatal terminations. This anatomic arrangement places the dopaminergic inputs in a position to regulate or gate the corticostriatal transmission (see figure 1, left panel). MSNs in the direct pathway carry dopamine D1-receptors, while those in the indirect pathway carry D2-receptors (Gerfen et al., 1990). The direct and indirect pathways are thought to have opposing actions: Direct pathway activation may inhibit GPi/SNr activity, thereby disinhibiting thalamocortical interactions, while indirect pathway activation does the opposite. Put very simply, dopamine release from the nigrostriatal projection appears to facilitate transmission at corticostriatal synapses onto direct pathway-MSNs, and to reduce transmission along indirect pathway-MSNs (see, e.g. DeLong and Wichmann, 2007). Dopamine's net action may thus be to reduce GPi/SNr activity, thereby facilitating activity in thalamocortical projection neurons, and, through greater activation of the cerebral cortex, facilitating movement.

The model outlined above has been very helpful in studies of the anatomy and functions of the basal ganglia circuitry, but it clearly represents a simplified view. Many potentially important 
connections between the basal ganglia and brainstem or thalamic nuclei are not included in this model. Furthermore, the separation of striatofugal output pathways into direct and indirect pathways is unlikely to be absolute, considering the results of single-cell tracing studies that showed that at least some striatal output neurons project to both segments of the globus pallidus (Levesque and Parent, 2005, Parent et al., 1995, Wu et al., 2000). The notion that D1 and D2 receptors co-segregate with direct and indirect pathways, respectively, has also been challenged, by studies that demonstrate a high incidence of D1 and D2 receptor co-localization in striatal cells (Aizman et al., 2000, Surmeier et al., 1996). However, more recent studies using transgenic mice in which the cellular expression of green fluorescent protein (GFP) is driven by the D1- or by the D2-receptor promoter showed that GFP-expressing striatal neurons from D1-GFP mice express exclusively the mRNA for the D1 receptor, while GFP-expressing neurons in D2-GFP mice express only D2-receptor mRNA (Day et al., 2006, Wang et al., 2006), underscoring the anatomical separation of D1- and D2 receptors.

\section{Dopamine loss in the striatum}

In Parkinson's disease, the degeneration of dopaminergic SNc neurons and their projections to the striatum is a slowly evolving process that may take decades to develop. SNc projections to the putamen degenerate earlier than projections to associative or limbic portions of the striatum. Corresponding to this time course of degeneration, the motor symptoms and signs of Parkinson's disease develop before the non-motor signs.

Recognizable motor or non-motor signs appear only after substantial degeneration of the nigrostriatal neurons (affecting at least 70\%, e.g., Bernheimer et al., 1973), testament to the remarkable compensatory capacity within the dopaminergic system, or in the circuits it modulates.

Dopamine loss in the basal ganglia triggers prominent secondary morphological changes. One change that may have pathophysiologic significance is the reduction of the density of dendritic spines on MSNs, particularly in the putamen (e.g., Ingham et al., 1989, Villalba et al., 2006, Zaja-Milatovic et al., 2005), which may greatly alter corticostriatal transmission. Recent studies have suggested that MSNs with D2 receptors (belonging to the indirect pathway) may be preferentially affected by the spine loss, and that the loss of spines may involve the dysregulation of calcium channels (Day et al., 2006).

Dopamine depletion also triggers changes in the density and sensitivity of dopamine receptors. The mRNA expression for dopamine D2-receptors and binding sites in the striatum is increased in patients with Parkinson's disease and parkinsonian animals (Aubert et al., 2005, Bezard et al., 2001, Bokobza et al., 1984, Creese et al., 1977, Guigoni et al., 2005, Lee et al., 1978, Marshall et al., 1989). Changes (increases or decreases) in striatal D1-receptor binding were also reported in some studies (see, e.g., Buonamici et al., 1986, Marshall et al., 1989), but were not seen by other authors (Aubert et al., 2005, Bezard et al., 2001, Guigoni et al., 2005). Gerfen demonstrated that the expression of D1-receptor mRNA was specifically downregulated in direct-pathway MSNs, and that the expression of D2-receptor mRNA was upregulated in indirect pathway-MSNs (Gerfen et al., 1990).

The subcellular locations of dopamine receptors in the striatum may also change. Thus, the proportion of D1-receptors that are bound to the plasma membrane is greater, while the proportion in the cytoplasm is smaller, in parkinsonism than under normal condition (Guigoni et al., 2007). This is not the case at the level of direct-pathway terminations in GPi or SNr in MPTP-treated animals (Kliem et al., 2007b). The subcellular distribution of striatal D2receptors appears to be only modestly affected by MPTP treatment (Guigoni et al., 2007). 


\section{Changes in neuronal activity in the basal ganglia}

In the following sections, we will describe abnormalities in basal ganglia firing in parkinsonism, focusing on changes in firing rates, and on the development of abnormal burst patterns, oscillatory activity and synchrony between neurons. Such changes are readily apparent in the single-neuron recordings shown in figures 2 and 3. For clarity, we present these features separately, but it is important to realize that these abnormalities usually do not occur in isolation. For example, increases in burst discharges or increased synchrony often occur together with the development of abnormal oscillations in the basal ganglia-thalamocortical network of connections, and firing rate changes are strongly influenced by changes in burst firing.

\section{Altered firing rates, the 'rate model' of Parkinson's disease}

Chronic loss of dopamine results in significant changes in the firing rates of basal ganglia neurons, especially in the extrastriatal basal ganglia. Changes in the firing rates of MSNs have been difficult to identify, perhaps because MSNs are a heterogeneous population of neurons, and because dopamine loss affects corticostriatal transmission rather than directly altering the spontaneous activity of MSNs. Recent recordings in anesthetized 6-OHDA-treated rats, however, have shown less activity among direct pathway MSNs in parkinsonian animals than under normal conditions, while the spontaneous discharge and responses to cortical stimulation in indirect pathway MSNs are greater in dopamine-depleted animals than in normal ones (Mallet et al., 2006). It is not clear whether this is specifically due to changes in the dopaminergic control of corticostriatal transmission, or whether the cortical or thalamic inputs themselves are altered. Of course, the loss of MSN spines, described above, may also impact the activity of these cells.

Studies examining changes in firing rates in the basal ganglia of monkeys in response to MPTP treatment have revealed a combination of increased activity in STN and GPi and reduced activity in GPe (Bergman et al., 1994, Hassani et al., 1996, Miller and DeLong, 1987, Raz et al., 1996, Soares et al., 2004, Wichmann et al., 1999). These studies are also supported by electrophysiologic recordings in parkinsonian patients undergoing neurosurgical interventions (Dogali et al., 1994, Hutchison et al., 1994, Lozano et al., 1996, Taha et al., 1997). Together with measurements of brain metabolism (e.g., Mitchell et al., 1989, Schwartzman and Alexander, 1985a), the changes in firing rates in the extrastriatal basal ganglia led to the development of the 'rate model' of the pathophysiology of parkinsonism (Albin et al., 1989, DeLong, 1990). In its simplest form, this model explains the firing rate changes in the basal ganglia as the result of disturbances of the balance of activity in the direct and indirect pathways (figure 1, right panel). In this model, loss of D2 receptor activation reduces inhibition of corticostriatal transmission at indirect-pathway MSNs, which increases inhibition of GPe activity, disinhibits STN neurons, and therefore leads to excessive activity in targets of STN efferents, including GPi and SNr. In addition, the loss of dopamine decreases activation of striatal D1-receptors, which may disinhibit GPi and SNr neurons along the direct pathway. The resulting increase in activity of GPi and $\mathrm{SNr}$ neurons would lead to greater inhibition of neurons in the thalamus and brainstem (Albin et al., 1989, DeLong, 1990). As predicted by this (static) rate model of parkinsonism, inactivation of the overactive STN or GPi by lesioning reverses the motor signs of parkinsonism both in MPTP-treated monkeys and in patients with Parkinson's disease (Alvarez et al., 2005, Aziz et al., 1991, Baron et al., 1996, Bergman et al., 1990, Dogali et al., 1995, Gill and Heywood, 1998, Guridi et al., 1994, Laitinen, 1995, Lozano et al., 1995, Vitek et al., 2003).

The long-term functional changes that are described by the rate model suggest corresponding anatomical and biochemical changes, particularly in the function of GABAergic and glutamatergic pathways in the basal ganglia. Microdialysis studies in parkinsonian animals 
showed that the level of GABA is increased in GPe (Galeffi et al., 2003, Robertson et al., 1991), which is compatible with the notion that GPe-projecting indirect-pathway MSNs are overactive, but it is difficult to reconcile with the more recent view that a substantial proportion of the GABA in GPe is released from local collaterals of axons originating in the GPe itself. In the STN, where terminals of axons originating in GPe are the principal source of GABA, the GABA level is decreased (Soares et al., 2004), consistent with the reduction of GPe activity predicted by the 'rate model'. In the SNr, levels of GABA have been reported to be either increased (Windels et al., 2005) or unchanged (Galeffi et al., 2003, Ochi et al., 2004). In postmortem tissue from parkinsonian patients or animals, the level of GABA is unchanged in the extrastriatal basal ganglia (Calon et al., 1999, Kish et al., 1986).

Changes in GABAergic transmission have also been evaluated with measurements of mRNA or protein levels for the GABA-synthesizing enzyme glutamate decarboxylase (GAD), under the assumption that GAD levels reflect the activity of GABAergic pathways. In striatopallidal projection neurons and in GPi and SNr cells there is a selective increase in GAD mRNA in dopamine-depleted animals (Kincaid et al., 1992, Laprade and Soghomonian, 1999, Salin et al., 2002, Soghomonian et al., 1994, Soghomonian and Laprade, 1997). However, in GPe and STN, the level of GAD is unchanged (Pedneault and Soghomonian, 1994, Schneider and Wade, 2003, Soares et al., 2004), contrary to what the rate model would predict.

Finally, changes in GABAergic transmission have been assessed by measuring the binding or density of GABA receptors. Such changes are thought to be compensatory, and therefore opposite in polarity, to the changes in GABAergic activity. Consistent with increased GABA release in GPe, and reduced GABAergic inhibition of GPi and $\mathrm{SNr}$, there are decreases in GABA-A and GABA-B receptor binding or mRNA expression for these receptors in GPe, and increases in GPi/SNr, in parkinsonian patients or animals (e.g., Calon et al., 1999, Chadha et al., 2000, Gnanalingham and Robertson, 1993, Griffiths et al., 1990, Katz et al., 2005, Pan et al., 1985, Robertson et al., 1990).

Besides the GABAergic system, glutamatergic transmission has also been evaluated. There is no consensus regarding changes in the binding or expression of striatal ionotropic glutamate receptors (NMDA- and AMPA-type) in parkinsonism (Bernard et al., 1996, Betarbet et al., 2000, Betarbet et al., 2004, Dunah et al., 2000), but these receptors appear to be down-regulated in the output nuclei of the basal ganglia in parkinsonian patients and in dopamine-depleted animals (Bernard et al., 1996, Betarbet et al., 2000, Dunah et al., 2000). This is, perhaps a compensatory response reflecting increased activity in the glutamatergic STN.

Changes in metabotropic glutamate receptors are less well studied. Compared to the normal state, the mGluR $1 \alpha$ subtype of glutamate receptors is reduced in the GPi and SNr of MPTPtreated monkeys (Kaneda et al., 2005, Samadi et al., 2007). Reports of changes of the striatal expression or binding of the metabotropic glutamate receptor subtype mGluR2/3 are inconsistent (Samadi et al., 2007, Testa et al., 1998), and there appear to be regionally specific changes in the binding of mGluR5 receptors, which are increased in the non-motor portions of the striatum, but unchanged in the motor portion in MPTP-treated monkeys (Samadi et al., 2007).

The biochemical and anatomical changes that occur in the basal ganglia in response to dopamine depletion are obviously only partially consistent with the predictions of the 'rate model'. A number of observations indicate that the situation is more complex than suggested by the rate model alone. First, global increases or decreases in GPi activity, produced by local drug injections, do not necessarily produce parkinsonism or involuntary movements, respectively. Second, although the rate model predicts that GPe lesions and lesions of VA/VL should induce parkinsonism, neither type of lesion does so consistently (Canavan et al., 
1989, Soares et al., 2004). Third, the remarkable antiparkinsonian effects of focal electrical 'deep brain' stimulation (DBS) of the STN, a procedure that is thought to increase GPi output to the thalamus (Hashimoto et al., 2003, McIntyre et al., 2004), are contrary to the prediction of the rate model that such increased output should worsen rather than ameliorate parkinsonism. Finally, the reduced density of dendritic spines on indirect pathway-MSNs (described above) should reduce the overall activity along the striato-GPe pathway, contrary to the changes predicted by the rate model. These findings suggest that the rate model of parkinsonian pathophysiology is inadequate, and that other changes in basal ganglia activity, contribute to parkinsonism. These may include changes in the firing patterns of individual neurons, the responsiveness of these neurons to sensory inputs, and altered interactions within ensembles of neurons.

\section{Burst discharges}

In dopamine-depleted monkeys, distinct changes in burst firing have been identified in GPe, GPi and STN neurons (Bergman et al., 1994, Filion, 1979, Soares et al., 2004, Wichmann et al., 1999, Wichmann and Soares, 2006). The proportions of spikes within bursts, the proportions of time that the neurons spend in bursting activities, and the length of individual bursts are all increased (Wichmann and Soares, 2006). Likewise, in patients with Parkinson's disease, the incidence of burst firing in the basal ganglia was also reported to be high (Hutchison et al., 1994, Magnin et al., 2000). Bursting activity in the STN develops early in the course of dopamine depletion, along with changes in discharge rates and metabolic markers (Breit et al., 2007, Ni et al., 2001b, Vila et al., 2000).

The mechanism by which neuronal burst firing develops in parkinsonism has been extensively studied. While it is likely that bursting is related to dopamine loss in the striatum, loss of dopamine in other basal ganglia regions (such as the STN) may also be important (Ni et al., 2001a). For instance, dopamine acts locally to reduce inhibitory synaptic input to the STN (Shen and Johnson, 2000, but see Tofighy et al., 2003, Zhu et al., 2002b), and its absence may enhance the impact of synchronous GABAergic inputs on STN activity, resulting in rebound bursting (Bevan et al., 2007, Shen and Johnson, 2005). Activation of D2-receptors normalizes bursting of STN cells in slices obtained from dopamine-depleted animals (Zhu et al., 2002a).

The interplay between GPe and STN may contribute powerfully to the development of burst discharges in both nuclei (Ni et al., 2000a, Plenz and Kitai, 1999). The strongest argument for this hypothesis comes from the observation that, in a dopamine-free co-culture preparation, GPe and STN neurons form connections with one another and generate burst discharges that are abolished if the connections between the two neuronal cell populations are cut (Plenz and Kitai, 1999). In brain slice preparations, synchronous inputs from GPe hyperpolarize STN neurons, leading to rebound bursting in this nucleus (Beurrier et al., 1999, Bevan et al., 2007). The potential role of increased inhibition in the generation of (rebound-) burst discharges in the STN in parkinsonism has also been stressed in computational models of the basal ganglia (Gillies et al., 2002), and was apparent in our recent study of dopamine-depleted monkeys, in which the temporal structure of spike discharges occurring before bursts was found to be significantly altered in parkinsonism, with a lengthening of inter-spike intervals immediately preceding bursts, perhaps indicative of pre-burst inhibition (Wichmann and Soares, 2006).

Although it is likely that the emergence of excessive burst discharges alters information processing in the basal ganglia-thalamocortical circuitry, doubts remain as to whether bursting per se has pro-parkinsonian effects, because treatments with antiparkinsonian dopaminergic treatments do not consistently reduce burst firing in the basal ganglia of dopamine-depleted animals or patients. While SNr burst activity was reduced in dopamine-depleted rats that received intrastriatal injections of a D1-like receptor (D1LR) agonist (Tseng et al., 2000), the opposite occurred in other studies in which parkinsonian patients or animals were given 
dopaminergic drugs systemically (Lee et al., 2001, Levy et al., 2001). Local injections of a dopamine D1LR receptor agonists into the primate GPi or SNr, or D5 receptor activation in the rodent STN, also increased rather than decreased burst firing in these nuclei (Baufreton et al., 2003, Kliem et al., 2007a). One caveat is that the (potential) behavioral effect of the dopaminergic treatments in these studies was not clear. Further study is therefore needed to examine the effects of dopaminergic treatment on burst discharges in vivo specifically in animals in which a satisfactory antiparkinsonian effect has been achieved. It will also be important to monitor the state of arousal in these animals, which has rarely been reported to date: Burst firing in the basal ganglia increases strongly when animals become drowsy (DeLong, 1969), and drowsiness is known to be associated both with parkinsonism and with dopaminergic therapy (the interaction between sleep and parkinsonism-related changes in firing is discussed in Gatev et al., 2006, Gatev and Wichmann, 2004).

\section{Oscillations}

Another distinct abnormality in the electrical activity of basal ganglia neurons in parkinsonian animals and patients is the emergence of abnormal oscillatory activity, both at the single-cell level and in larger ensembles of neural elements. At the level of single cells, oscillations in the alpha- and beta- frequency ranges are prominent in recordings in GPe, GPi, and STN of MPTPtreated monkeys, and in parkinsonian patients undergoing functional neurosurgery (see, e.g., Gatev et al., 2006, Levy et al., 2002b, Rivlin-Etzion et al., 2006, Weinberger et al., 2006).

Recent studies have also investigated oscillations in field potential recordings made with DBS electrodes implanted in GPi and STN of parkinsonian patients. Although the process(es) that contribute to the pathological field potential oscillations are not fully understood, it is likely that they reflect oscillatory synaptic or neuronal activities that are generated by large groups of neural elements, separated by considerable distances (millimeters). In fact, the anatomical targets (especially the STN) are often smaller than the spacing of the electrodes used to record the LFP signals, so that structures within and outside the target nuclei likely contribute to the recorded potentials. In several studies, LFP oscillations in the beta frequency band have, however, been shown to be correlated with neuronal activity specifically in the STN of parkinsonian patients (for example, Kuhn et al., 2005, Levy et al., 2002a, Weinberger et al., 2006). In patients in whom dopaminergic medications had been withheld overnight, the spectral power of the recorded LFP potentials in STN and GPi showed peaks in the 10-30 Hz range which disappeared when the patient was treated with dopaminergic agents (Brown et al., 2001, Hammond et al., 2007). The disappearance of the pathological alpha- and beta band oscillations is often associated with the emergence of gamma-band oscillations.

The mechanisms by which oscillations of single cells or groups of neural elements develop in parkinsonism are not clear. It is also not clear why the circuitry involved in the generation of the LFP signals preferentially produces beta-band oscillations (and not oscillations in other frequency ranges). Given the massive dopamine loss in the striatum in Parkinson's disease, it would seem logical that they arise from changes in striatal activity. However, although neural elements in the striatum are capable of generating such oscillations (Berke et al., 2004, Courtemanche et al., 2003, Masimore et al., 2004), the very low and generally non-rhythmic activity of striatal output neurons (MSNs) make it seem unlikely that oscillatory activities originating in the striatum strongly influence the remainder of the basal ganglia circuitry. It is more likely that changes in the extrastriatal basal ganglia, specifically the interplay between GPe and STN, may be important in the development of oscillations. As mentioned above, STN cells generate rebound bursts in response to transient volleys of inhibitory inputs from GPe (Plenz and Kitai, 1999). This, in turn, may trigger additional bursts in GPe, creating a system of self-sustaining oscillatory activity involving both nuclei. The degree to which inputs from the striatum modulate the function of the proposed STN-GPe 'pacemaker' remains unclear 
(see, e.g., Bevan et al., 2002, Loucif et al., 2005, Stanford, 2003, Terman et al., 2002). The occurrence of oscillations in the GPe-STN network may be modulated by cortical inputs to the STN (Hartmann-von Monakow et al., 1978, Nambu et al., 2002b) or by thalamic inputs (Castle et al., 2005). Field potential studies in parkinsonian patients have demonstrated that oscillatory activity, once generated in the STN, can be transmitted to the GPi (Brown et al., 2004), and may, presumably, affect the entire basal ganglia-thalamocortical network (see below). A clear caveat with the STN-GPe pacemaker model is that the oscillations in the dopamine-free STN/ GPe co-cultures (Plenz and Kitai, 1999) occurred at very low frequencies $(<1 \mathrm{~Hz})$. The relationship between these low-frequency oscillations and the alpha- and beta oscillations seen in patients with Parkinson's disease has not yet been determined.

Although the STN-GPe pacemaker mechanism is an attractive explanation for the generation of oscillatory activity in the basal ganglia, there is no in vivo evidence of an STN-GPe pacemaker. An alternative possibility is that the oscillations observed in basal ganglia, thalamus and cortex (see below) are not a primary basal ganglia phenomenon but are generated by other mechanisms and/or at other locations (for instance in thalamus and cortex, as discussed in Gatev et al., 2006, Magill et al., 2000, Magill et al., 2001).

\section{Abnormal synchrony}

Under normal conditions, neighboring basal ganglia neurons fire in an uncorrelated fashion (Bergman et al., 1994, Jaeger et al., 1994, Wilson et al., 2004). In the dopamine-depleted state, however, the synchrony between neighboring basal ganglia cells, and even between nuclei, is significantly increased, usually together with the emergence of oscillatory activity (Hammond et al., 2007). These changes are readily seen in the multi-electrode recording examples shown in figure 3. Increased oscillatory synchrony is likely to be a direct result of the loss of dopamine in the parkinsonian brain, as systemically applied dopaminergic agents rapidly reduce the pathological interneuronal synchrony (Heimer et al., 2002, Levy et al., 2002a). Synchronous activities could, for instance, be produced in the striatum through enhancement of electrotonic coupling between striatal cells (Berretta et al., 2001, Cepeda et al., 1989, O'Donnell and Grace, 1993, Onn and Grace, 2000), or through changes in interneuronal or axon collateral activity (Guzman et al., 2003). Alternatively, changes in the general level of striatal inhibition of pallidal activity may act to induce synchrony in the extrastriatal basal ganglia (Terman et al., 2002). While it is also possible in principle that dopamine loss outside of the striatum promotes synchrony, there is, thus far, little evidence for this (see, e.g., Wilson et al., 2004).

\section{Changes in sensory response patterns and changes in task-related activity of basal ganglia neurons}

Under normal conditions, many neurons within the motor territory of each of the basal ganglia structures respond to proprioceptive input. Appropriate modulation of basal ganglia activity through such inputs may be important to gate and restrict cortical activities related to specific movements or other activities. Sensory responses in the striatum can be assumed to be the result of direct cortical inputs to this structure, while proprioceptive responses in the extrastriatal basal ganglia are, at least in part, due to inputs reaching the STN via the cortico-subthalamic projection (see figure 1, left panel and, e.g., Hamada and DeLong, 1992,Hartmann-von Monakow et al., 1978,Nambu et al., 2002a). Pallidal recordings in MPTP-treated animals showed a reduction in the specificity of such responses (Rothblat and Schneider, 1995,Schneider and Rothblat, 1996), and an increase in the proportion of neurons with excitatory responses (Boraud et al., 2000). In addition, rodent studies showed that the normal arrangement of striatal neurons into clusters that respond to sensory inputs appears to be fragmented in the dopamine-depleted state (Cho et al., 2002,Prokopenko et al., 2004). These sensory changes may be due to abnormal basal ganglia processing, or may reflect abnormal cortical inputs to the basal ganglia. Through disruption of cortico-subcortical feedback 
mechanisms that control the extent and speed of movement, they may contribute to abnormal scaling of movements and bradykinesia in Parkinson's disease (Wichmann and DeLong, 1993).

\section{Changes in thalamic activity}

In this section, we will consider parkinsonism-related changes in VA/VL separately from those occurring in $\mathrm{CM} / \mathrm{Pf}$, because these thalamic nuclear groups appear to have different physiologic functions. VA/VL are part of the basal ganglia-thalamocortical circuitry, while CM/Pf participate in circuits by which basal ganglia output is fed back into the putamen.

Metabolic studies in MPTP-treated monkeys have suggested that the metabolism in the thalamic VA and VL nuclei is increased in parkinsonism (Mitchell et al., 1989, Rolland et al., 2007), perhaps reflecting increased basal ganglia input to this area. Studies of thalamic firing rate changes in parkinsonism have been inconclusive. Earlier studies in MPTP-treated monkeys reported a small decrease of neuronal activity in basal ganglia-receiving areas of the thalamus (Vitek et al., 1994), but this was not confirmed by later studies in human patients or MPTPtreated monkeys (Molnar et al., 2005, Pessiglione et al., 2005). There is, however, consistency among various reports that changes in thalamic firing patterns generally mirror those found in the basal ganglia output nuclei. In MPTP-treated monkeys, the incidence of burst discharges was found to be increased in VL (Guehl et al., 2003, Kaneoke and Vitek, 1995, Pessiglione et al., 2005, Vitek et al., 1994), and a high level of burst firing in this area has also been documented in human patients with Parkinson's disease (Magnin et al., 2000, Molnar et al., 2005, Zirh et al., 1998). Several authors have reported that the thalamic bursts show characteristics of low-threshold calcium bursting which could indicate that they are generated in the context of hyperpolarization of thalamic neurons, induced by increased GABAergic basal ganglia input (Kaneoke and Vitek, 1995, Magnin et al., 2000), but other authors have failed to find evidence for low-threshold calcium bursting (Molnar et al., 2005, Zirh et al., 1998). A second finding similar to those in the basal ganglia is that pathological oscillations develop in the thalamus (e.g., Guehl et al., 2003, Magnin et al., 2000, Raeva et al., 1999, Zirh et al., 1998). Coherent theta-band oscillations that engage both thalamus and cortex have been identified in studies in which thalamic field potentials were recorded together with cortical EEG in humans (Sarnthein and Jeanmonod, 2007). Finally, there is also an increase in the correlation of the spiking activities of neighboring neurons in VA/VL (Pessiglione et al., 2005). Studies of the sensory response properties of VA/VL neurons have suggested that parkinsonism is associated with reduced specificity of such responses in MPTP-treated monkeys (Pessiglione et al., 2005), a finding that was different from the results of studies in humans (Kiss et al., 2003, Magnin et al., 2000).

With regard to the $\mathrm{CM} / \mathrm{Pf}$ nuclei, there is indirect evidence that GABAergic basal ganglia output to these nuclei is increased in parkinsonism, in line with predictions of the rate model of parkinsonism (figure 1). Thus, GABA-A receptor subunit expression in Pf is decreased in dopamine-depleted rats (Chadha et al., 2000), and a (transient) decrease in average Pf firing rates has been documented in such animals (Ni et al., 2000b). There is also evidence that MPTPexposure in monkeys leads to changes in glucose utilization in CM/Pf (Palombo et al., 1990), suggesting changes in synaptic or neuronal activity. The significance of activity changes in $\mathrm{CM} / \mathrm{Pf}$ in the development of parkinsonism has not been explored in detail. According to the circuitry model in figure 1, parkinsonism may result in a reduction of $\mathrm{CM} / \mathrm{Pf}$ activity which may, secondarily, result in reduced driving of 'direct' pathway MSNs (Sidibe and Smith, 1996), and worsening of parkinsonism. This pathophysiologic scheme may be too simplistic, however, because the effects of altered patterns of basal ganglia input to $\mathrm{CM} / \mathrm{Pf}$, and of $\mathrm{CM}$ outputs acting on striatal interneurons are not taken into account. 
Interestingly, many of the electrophysiologic changes in the thalamus do not seem to be specific to the thalamic nuclei that receive basal ganglia inputs (VA/VL and CM/Pf). Thus, burst firing, oscillations and abnormal sensory processing have also been found in the nuclei of the thalamus that receive cerebellar input (Guehl et al., 2003, Pessiglione et al., 2005).

In addition to the limited evidence suggesting that neuronal activity in CM/Pf is altered, as a consequence of the loss of dopamine in the basal ganglia, it has been shown in autopsy studies that $\mathrm{CM} / \mathrm{Pf}$ may also be affected by the neurodegenerative process in Parkinson's disease: more than 50\% of CM/Pf neurons have degenerated in patients with (end-stage) Parkinson's disease (Henderson et al., 2000), especially in CM (Henderson et al., 2000, but see ref. Xuereb et al., 1991). Neuron loss has also been seen in the Pf of dopamine-depleted rodents (Aymerich et al., 2006, Henderson et al., 2005). The potential cause(s) and significance of these findings remain(s) unclear.

\section{Changes in cortical activity}

Early 2-deoxyglucose studies suggested that cortical activation (at rest) is globally reduced in MPTP-treated monkeys (Schwartzman and Alexander, 1985b). Later studies using positron emission tomography (PET) and functional magnetic resonance imaging (fMRI) in parkinsonian patients documented changes in activity both at rest and during the performance of motor or cognitive tasks. The PET studies demonstrated that cortical activation in motor tasks is reduced in parkinsonism, specifically in the supplementary motor area (SMA) and in the anterior cingulate cortex (Brooks, 1997, Haslinger et al., 2001, Jahanshahi et al., 1995, Jenkins et al., 1992, Playford et al., 1992, Samuel et al., 1997, Thobois et al., 2000, Turner et al., 2003).

Besides the obvious motor impairments, parkinsonian patients also show abnormalities in cognitive tasks, perhaps associated with the loss of dopamine in non-motor portions of the striatum (Bruck et al., 2001, Marie et al., 1999). PET studies in such patients have suggested that at least some of the cognitive deficits could be explained by abnormal activation of nonmotor areas of the basal ganglia (Dagher et al., 2001).

In parkinsonian patients, the performance of motor and other tasks often recruits brain areas that are not activated in non-parkinsonian individuals, such as areas in the lateral premotor cortex, cerebellum and posterior parietal and occipital lobes (e.g., Samuel et al., 1997, Thobois et al., 2000, Turner et al., 2003). Similarly, cognitive tasks may affect activation in areas that are not normally activated (Dagher et al., 2001, Grossman et al., 2003, Moody et al., 2004). The aberrant patterns of activation are at least partially reversed by dopaminergic and other treatments (Haslinger et al., 2001, Peters et al., 2003). These studies provide evidence that dopamine depletion may not only disturb the function of those frontal areas of the cerebral cortex that receive direct input from the basal ganglia (via the thalamus), but may also result in compensatory shifts in activation towards other areas of cortex.

A small number of electrophysiologic studies have examined changes in cortical activities in MPTP-treated monkeys. These studies found that the activation of motor cortex or the supplementary motor area is reduced in these animals (Watts and Mandir, 1992), and that the synchrony between neurons is increased (Goldberg et al., 2002). EEG studies in patients have shown that parkinsonism may be associated with abnormal beta-band synchronization of cortical networks, (Silberstein et al., 2005), and a failure to modulate frontal and central betaband activity with movement (Brown and Marsden, 1998, Brown, 2003). 


\section{Parkinsonism as a network phenomenon}

It is likely that all of the firing rate and pattern changes described in the previous sections occur together and eventually result in the emergence of parkinsonism. A general link between the changes in cortical activity and the previously described subcortical changes emerges from voxel-comparing network analyses of PET images which show that cortical activation patterns relate to activity changes in the basal ganglia in individuals with Parkinson's disease (Antonini et al., 1998, Eidelberg, 1998).

The strongest case for the notion that specific network-wide disturbances of activity are associated with, and may contribute to the development of, parkinsonism has been based on the finding that abnormal and synchronous oscillations appear to permeate the entire basal ganglia-thalamocortical circuitry (Brown, 2003, Hammond et al., 2007). Oscillatory single cell spiking in the basal ganglia has been found to be correlated to oscillatory activity in cortex, and dopamine depletion strengthens the correlation between frontal EEG activity and single cell discharges in STN, GPi, and GPe (Gatev and Wichmann, 2003, Goldberg et al., 2002, Magill et al., 2000, Sharott et al., 2005, Urbain et al., 2000, Wichmann et al., 2002). Many of these studies were done under experimental conditions in which the basal ganglia were the target of synchronous inputs, such as during anesthesia or slow wave sleep (Magill et al., 2000, Urbain et al., 2000). In recent studies in normal and MPTP-treated monkeys, we have extended such observations to the awake resting state, combining EEG recordings with recordings of single neuron activity (Gatev and Wichmann, unpublished). In our experiments, spiking activity in GPe and GPi was associated with shifts from pre-spike synchronization of EEG in primary motor cortex and supplementary motor area, to post-spike desynchronization. STN spiking had the opposite effect, with pre-spike desynchronization and post-spike synchronization. These changes occurred in parallel with shifts in the covariance between betaand gamma-frequency bands within the EEG-rhythms. In parkinsonism, the spiking-related changes in cortical synchronization were reduced in EEG segments aligned to STN spikes, and increased in segments aligned to spikes in GPe or GPi. Such changes were not limited to the beta-band, but involved a larger spectrum of frequencies, including alpha-, beta- and gammabands. Spiking-related changes in beta/gamma band covariance were reduced in all three nuclei (see also, Gatev et al., 2006).

Field potential recordings have also shown that beta-band activity in the STN and GPi is coherent with EEG in unmedicated parkinsonian patients (Brown and Williams, 2005, Fogelson et al., 2005, Gatev et al., 2006), and that beta-band EEG oscillations are reduced by therapeutically effective DBS of the STN (Silberstein et al., 2005).

\section{Do electrophysiologic abnormalities in the basal ganglia-thalamocortical circuitry cause parkinsonism?}

There is little doubt that moderate or severe forms of parkinsonism are associated with increased bursting, oscillatory activity, changes in interneuronal synchrony, changes in the processing of sensory information, and perhaps changes in firing rates. The immediate beneficial effects of focal lesions or DBS in the basal ganglia suggests that such changes may contribute to the development of the behavioral manifestations of the disease. However, the importance of specific electrophysiologic features in basal ganglia, thalamic or cortical activity for the development of the behavioral signs of parkinsonism has not been fully worked out yet.

As it seems increasingly doubtful that changes in firing rates or increased bursting are (strongly) pro-parkinsonian, synchronous oscillations within the basal ganglia-thalamocortical circuits are the current lead suspect for a pro-parkinsonian circuit dysfunction (Brown, 2003).

However, direct links between these oscillations and specific parkinsonian deficits are still 
missing. It may seem logical that the oscillations may result in tremor (Bergman and Deuschl, 2002, Deuschl et al., 2000, Levy et al., 2002b, Wang et al., 2005), but a specific relationship between tremor movements and oscillatory basal ganglia or cortical firing is often difficult to detect, perhaps due to the fact that multiple independent oscillators may be at work at any given time (Ben-Pazi et al., 2001, Bergman et al., 1998b, Levy et al., 2002b, Priori et al., 2004, Raz et al., 2000, Rivlin-Etzion et al., 2008). It is also obvious from primate and human recordings that strongly oscillatory neuronal activity can, in fact, occur without overt tremor (Levy et al., 2002a, Raz et al., 2001, Soares et al., 2004, Wichmann et al., 1999). Another possibility is that the disruption of normal processing in the basal ganglia and associated areas by the excessive alpha- and beta-band oscillations is important for the development of akinesia. This possibility is supported by studies in which $10 \mathrm{~Hz}$ - or $20 \mathrm{~Hz}$-stimulation in the STN area with a DBS lead resulted in a moderate increase in akinesia (Chen et al., 2007, Timmermann et al., 2004), and by the finding that anti-akinetic treatments such as levodopa administration or STN-DBS lead to a reduction of beta-band oscillations in the basal ganglia and cortex in patients with Parkinson's disease (Brown et al., 2004, Hammond et al., 2007, Kringelbach et al., 2007, Kuhn et al., 2006, Wingeier et al., 2006).

While the aforementioned studies in moderately or severely parkinsonian patients or animals suggest that synchronous oscillatory activity is associated with parkinsonism, these studies do not prove causality. Thus, it is not known whether 10- or $20 \mathrm{~Hz}$ stimulation actually induces low-frequency oscillations in the basal ganglia-thalamocortical network, and, if so, whether the oscillation act through disruption of information processing, or through associated changes in transmitter levels or other biochemical alterations. It is also not known whether levodopa treatments or STN-DBS reduce akinesia because the reduce beta-band activity, or whether the reduction of these oscillations is simply correlated with (but not causal to) the beneficial motor effects.

It is important to keep such caveats in mind, because recent studies in monkeys that underwent a gradual MPTP-treatment protocol that slowly induced parkinsonism cast doubt on the notion that synchronous oscillatory firing truly contributes to (early) parkinsonism (Leblois et al., 2007). In these single-neuron recording studies, synchrony and oscillations in neuronal spiking activity were late phenomena, developing after the first appearance of bradykinesia and akinesia. The authors detected, however, earlier changes in sensory processing. This topic clearly deserves more study. Follow-up studies also need to take advantage of electrophysiologic methods other than single-neuron recordings, such as LFP recordings.

\section{Changes in brainstem activity}

Our understanding of the pathophysiologic changes that occur in areas outside of the basal ganglia-thalamocortical loops remains rudimentary. However, there is evidence that abnormalities in brainstem regions, specifically the PPN, may be involved in the development of some of the core signs of parkinsonism. The PPN is tightly connected to the basal ganglia (Mena-Segovia et al., 2004). Animal studies demonstrate that stimulation of the PPN area increases movement (Nandi et al., 2002b), while inhibition or lesioning of the PPN decreases it (Aziz et al., 1998, Kojima et al., 1997, Munro-Davies et al., 2001). In MPTP-treated monkeys, akinesia is reduced by injections of a GABA receptor antagonist into the PPN (Nandi et al., 2002a) or by low-frequency electrical stimulation of the PPN area (Pahapill and Lozano, 2000). Studies in 6-OHDA-treated rats have suggested that PPN activity is increased in the dopamine-depleted state (Breit et al., 2001), and that lesions of the PPN in 6-OHDA treated rats reduce some of the discharge abnormalities in STN and SNr (Breit et al., 2006).

Based on this evidence that PPN may be affected by dopamine depletion, and that PPN interventions may affect movement, several preliminary studies of the effects of PPN 
stimulation in parkinsonian patients have been carried out (Mazzone et al., 2005, Plaha and Gill, 2005, Stefani et al., 2007). These (unblinded) studies have reported significant improvements in parkinsonian signs, specifically in gait and postural instability, i.e., symptoms that poorly respond to other antiparkinsonian therapies. These attempts to treat parkinsonism with interventions directed at the PPN are obviously still in their infancy at this time. The mechanisms by which the effects are produced, and the relationship of such movement effects to basal ganglia functions are poorly understood. It has been speculated that manipulation of PPN activity may affect the excitatory input from PPN to SNc neurons, or may act through dopamine-independent mechanisms, perhaps related to the extensive local and spinal connections of this nucleus (see, e.g., Kojima et al., 1997, Mena-Segovia et al., 2004, Nandi et al., 2002a). At this time, it remains uncertain whether the effects of PPN interventions are specific for Parkinson's disease, or whether other forms of gait or postural instability may also respond (see, e.g., Shih and Tarsy, 2007).

Caution is necessary in the interpretation of the effects of surgical PPN interventions in animals or humans, because (1) this nucleus is heterogeneous, (2) it is not well demarcated from surrounding brain regions, and (3) the spread of current of drugs from the site of intervention to surrounding areas cannot be excluded (see, for instance, discussion in Kringelbach et al., 2007). The optimal stereotactic target of surgical interventions in humans has not been determined, and the electrophysiologic properties of the PPN and nuclei around it are not fully defined, rendering electrophysiologic targeting of the surgical procedures more difficult than it is in the basal ganglia (see, for instance, Mazzone et al., 2005, Mazzone et al., 2007, Stefani et al., 2007, Zrinzo et al., 2007a, Zrinzo et al., 2007b)

\section{Conclusion}

With clear evidence for concurrent abnormalities in the basal ganglia, thalamus and cortex, parkinsonism is now recognized as a disease of a distributed brain network. Highly specific changes in neuronal activity, produced by dopamine loss in the putamen and other basal ganglia nuclei, or by the loss of dendritic spines on striatal output neurons, appear to severely disrupt the activity of neurons throughout the basal ganglia, thalamus and cortex, and may even lead to the aberrant activation of brain areas that are not part of the immediate basal gangliathalamocortical circuitry, eventually resulting in parkinsonism.

There are obvious limitations to our current understanding of this pathophysiologic scheme. First, the specific involvement and changes in striatum, brainstem, thalamus and cortex are less well understood than the changes in GPe, STN and GPi/SNr. Second, dopamine depletion develops very rapidly in the commonly used toxin-based animal models of dopaminedepletion, so that the gradual changes in basal ganglia-thalamocortical activity during the process of dopamine loss in parkinsonism cannot be adequately studied. Third, the lack of methods to identify reliably the 'direct' pathway in vivo has led to a (possibly undue) emphasis on the role of abnormalities in the indirect pathway, while the role of the changes in the direct pathway is not clear. Fourth, the involvement of areas outside of the basal ganglia, such as the PPN, in the development of parkinsonism awaits further study. Finally, it remains largely unknown how the development of the behavioral motor signs of Parkinson's disease is specifically related to the aforementioned abnormalities in activity patterns in the basal ganglia and related areas.

While the current dopamine replacement therapies offer excellent symptomatic benefits in many patients with parkinsonism, these treatments are often accompanied by severe side effects, and by wearing-off phenomena and other motor fluctuations. More detailed characterization of abnormalities in brain activity in parkinsonism will help us to develop better and more specific antiparkinsonian treatments. The insight that parkinsonism is a network 
disorder has already stimulated the development of local neurosurgical interventions in the basal ganglia to influence the activity of the entire basal ganglia-thalamocortical network of connections, and thereby to ameliorate parkinsonism: Small GPi lesions or focal electrical stimulation of STN or GPi now provide patients with remarkable symptomatic benefits. In the future, a better understanding of the pathophysiologic changes in activity may also help us to develop pharmacologic or genetic treatments by which firing abnormalities in the basal ganglia-thalamocortical circuits can be specifically ameliorated.

\section{Acknowledgements}

This work was supported by grants from the National Institute of Neurological Disorders and Stroke (NS042250, NS049474 and NS054976), and an institutional NIH grant (RR-000165) to the Yerkes National Primate Research Center.

\section{References}

Aizman O, Brismar H, Uhlen P, Zettergren E, Levey AI, Forssberg H, Greengard P, Aperia A. Anatomical and physiological evidence for D1 and D2 dopamine receptor colocalization in neostriatal neurons. Nature Neuroscience 2000;3:226-230.

Albin RL, Young AB, Penney JB. The functional anatomy of basal ganglia disorders. Trends Neurosci 1989;12:366-375. [PubMed: 2479133]

Alexander GE, DeLong MR, Strick PL. Parallel organization of functionally segregated circuits linking basal ganglia and cortex. AnnRevNeurosci 1986;9:357-381.

Alexander GE, Crutcher MD, DeLong MR. Basal ganglia-thalamocortical circuits: parallel substrates for motor, oculomotor, 'prefrontal' and 'limbic' functions. Prog Brain Res 1990;85:119-146. [PubMed: 2094891]

Alvarez L, Macias R, Lopez G, Alvarez E, Pavon N, Rodriguez-Oroz MC, Juncos JL, Maragoto C, Guridi J, Litvan I, Tolosa ES, Koller W, Vitek J, DeLong MR, Obeso JA. Bilateral subthalamotomy in Parkinson's disease: initial and long-term response. Brain 2005;128:570-583. [PubMed: 15689366]

Antonini A, Moeller JR, Nakamura T, Spetsieris P, Dhawan V, Eidelberg D. The metabolic anatomy of tremor in Parkinson's disease. Neurology 1998;51:803-810. [PubMed: 9748030]

Aubert I, Guigoni C, Hakansson K, Li Q, Dovero S, Barthe N, Bioulac BH, Gross CE, Fisone G, Bloch $\mathrm{B}$, Bezard E. Increased D1 dopamine receptor signaling in levodopa-induced dyskinesia. Ann Neurol 2005;57:17-26. [PubMed: 15514976]

Aymerich MS, Barroso-Chinea P, Perez-Manso M, Munoz-Patino AM, Moreno-Igoa M, GonzalezHernandez T, Lanciego JL. Consequences of unilateral nigrostriatal denervation on the thalamostriatal pathway in rats. Eur J Neurosci 2006;23:2099-2108. [PubMed: 16630057]

Aziz TZ, Peggs D, Sambrook MA, Crossman AR. Lesion of the subthalamic nucleus for the alleviation of 1-methyl-4-phenyl-1,2,3,6-tetrahydropyridine (MPTP)-induced parkinsonism in the primate. Movement Disorders 1991;6:288-292. [PubMed: 1758446]

Aziz TZ, Davies L, Stein J, France S. The role of descending basal ganglia connections to the brain stem in parkinsonian akinesia. Br J Neurosurg 1998;12:245-249. [PubMed: 11013688]

Baron MS, Vitek JL, Bakay RA, Green J, Kaneoke Y, Hashimoto T, Turner RS, Woodard JL, Cole SA, McDonald WM, DeLong MR. Treatment of advanced Parkinson's disease by posterior GPi pallidotomy: 1-year results of a pilot study. Annals of Neurology 1996;40:355-366. [PubMed: 8797525]

Baufreton J, Garret M, Rivera A, de la Calle A, Gonon F, Dufy B, Bioulac B, Taupignon A. D5 (not D1) dopamine receptors potentiate burst-firing in neurons of the subthalamic nucleus by modulating an L-type calcium conductance. J Neurosci 2003:816-825. [PubMed: 12574410]

Ben-Pazi H, Bergman H, Goldberg JA, Giladi N, Hansel D, Reches A, Simon ES. Synchrony of rest tremor in multiple limbs in parkinson's disease: evidence for multiple oscillators. JNeural Trans 2001;108:287-296.

Bergman H, Wichmann T, DeLong MR. Reversal of experimental parkinsonism by lesions of the subthalamic nucleus. Science 1990;249:1436-1438. [PubMed: 2402638] 
Bergman H, Wichmann T, Karmon B, DeLong MR. The primate subthalamic nucleus. II Neuronal activity in the MPTP model of parkinsonism. J Neurophysiol 1994;72:507-520. [PubMed: 7983515]

Bergman H, Feingold A, Nini A, Raz A, Slovin H, Abeles M, Vaadia E. Physiological aspects of information processing in the basal ganglia of normal and parkinsonian primates. Trends Neurosci 1998a;21:32-38. [PubMed: 9464684]

Bergman H, Raz A, Feingold A, Nini A, Nelken I, Hansel D, Ben-Pazi H, Reches A. Physiology of MPTP tremor. Movement Disorders 1998b;13(Suppl 3):29-34. [PubMed: 9827591]

Bergman H, Deuschl G. Pathophysiology of Parkinson's disease: from clinical neurology to basic neuroscience and back. Mov Disord 2002;17(Suppl 3):S28-40. [PubMed: 11948753]

Berke JD, Okatan M, Skurski J, Eichenbaum HB. Oscillatory entrainment of striatal neurons in freely moving rats. Neuron 2004:883-896. [PubMed: 15363398]

Bernard V, Gardiol A, Faucheux B, Bloch B, Agid Y, Hirsch EC. Expression of glutamate receptors in the human and rat basal ganglia: effect of the dopaminergic denervation on AMPA receptor gene expression in the striatopallidal complex in Parkinson's disease and rat with 6-OHDA lesion. J Comp Neurol 1996;368:553-568. [PubMed: 8744443]

Bernheimer H, Birkmayer W, Hornykiewicz O, Jellinger K, Seitelberger F. Brain dopamine and the syndromes of Parkinson and Huntington. JNeurolSci 1973;20:415-455.

Berretta N, Paolucci E, Bernardi G, Mercuri NB. Glutamate receptor stimulation induces a persistent rhythmicity of the GABAergic inputs to rat midbrain dopaminergic neurons. Eur J Neurosci 2001;14:777-784. [PubMed: 11576181]

Betarbet R, Porter RH, Greenamyre JT. GluR1 glutamate receptor subunit is regulated differentially in the primate basal ganglia following nigrostriatal dopamine denervation. J Neurochem 2000;74:11661174. [PubMed: 10693949]

Betarbet R, Poisik O, Sherer TB, Greenamyre JT. Differential expression and ser897 phosphorylation of striatal N-methyl-d-aspartate receptor subunit NR1 in animal models of Parkinson's disease. Exp Neurol 2004;187:76-85. [PubMed: 15081590]

Beurrier C, Congar P, Bioulac B, Hammond C. Subthalamic nucleus neurons switch from single-spike activity to burst-firing mode. J Neurosci 1999;19:599-609. [PubMed: 9880580]

Bevan MD, Magill PJ, Terman D, Bolam JP, Wilson CJ. Move to the rhythm: oscillations in the subthalamic nucleus-external globus pallidus network. Trends Neurosci 2002;25:525-531. [PubMed: 12220881]

Bevan MD, Hallworth NE, Baufreton J. GABAergic control of the subthalamic nucleus. Prog Brain Res 2007;160:173-188. [PubMed: 17499114]

Bezard E, Dovero S, Prunier C, Ravenscroft P, Chalon S, Guilloteau D, Crossman AR, Bioulac B, Brotchie JM, Gross CE. Relationship between the appearance of symptoms and the level of nigrostriatal degeneration in a progressive 1-methyl-4-phenyl-1,2,3,6-tetrahydropyridine-lesioned macaque model of Parkinson's disease. J Neurosci 2001;21:6853-6861. [PubMed: 11517273]

Bokobza B, Ruberg M, Scatton B, Javoy-Agid F, Agid Y. [3H]spiperone binding, dopamine and HVA concentrations in Parkinson's disease and supranuclear palsy. Eur J Pharmacol 1984;99:167-175. [PubMed: 6734727]

Boraud T, Bezard E, Bioulac B, Gross CE. Ratio of inhibited-to-activated pallidal neurons decreases dramatically during passive limb movement in the MPTP-treated monkey. Journal of Neurophysiology 2000;83:1760-1763. [PubMed: 10712496]

Braak H, Bohl JR, Muller CM, Rub U, de Vos RA, Del Tredici K. Stanley Fahn Lecture 2005: The staging procedure for the inclusion body pathology associated with sporadic Parkinson's disease reconsidered. Mov Disord 2006;21:2042-2051. [PubMed: 17078043]

Breit S, Bouali-Benazzouz R, Benabid AL, Benazzouz A. Unilateral lesion of the nigrostriatal pathway induces an increase of neuronal activity of the pedunculopontine nucleus, which is reversed by the lesion of the subthalamic nucleus in the rat. Eur J Neurosci 2001;14:1833-1842. [PubMed: 11860479]

Breit S, Lessmann L, Unterbrink D, Popa RC, Gasser T, Schulz JB. Lesion of the pedunculopontine nucleus reverses hyperactivity of the subthalamic nucleus and substantia nigra pars reticulata in a 6hydroxydopamine rat model. Eur J Neurosci 2006;24:2275-2282. [PubMed: 17042796] 
Breit S, Bouali-Benazzouz R, Popa RC, Gasser T, Benabid AL, Benazzouz A. Effects of 6hydroxydopamine-induced severe or partial lesion of the nigrostriatal pathway on the neuronal activity of pallido-subthalamic network in the rat. Exp Neurol 2007;205:36-47. [PubMed: 17395181]

Brooks DJ. PET and SPECT studies in Parkinson's disease. Baillieres Clinical Neurology 1997;6:6987.

Brown P, Marsden CD. What do the basal ganglia do? Lancet 1998;351:1801-1804. [PubMed: 9635969]

Brown P, Oliviero A, Mazzone P, Insola A, Tonali P, Di Lazzaro V. Dopamine dependency of oscillations between subthalamic nucleus and pallidum in Parkinson's disease. J Neurosci 2001;21:1033-1038. [PubMed: 11157088]

Brown P. Oscillatory nature of human basal ganglia activity: relationship to the pathophysiology of Parkinson's disease. Movement Disorders 2003;18:357-363. [PubMed: 12671940]

Brown P, Mazzone P, Oliviero A, Altibrandi MG, Pilato F, Tonali PA, Di Lazzaro V. Effects of stimulation of the subthalamic area on oscillatory pallidal activity in Parkinson's disease. Exp Neurol 2004;188:480-490. [PubMed: 15246847]

Brown P, Williams D. Basal ganglia local field potential activity: character and functional significance in the human. Clin Neurophysiol 2005;116:2510-2519. [PubMed: 16029963]

Bruck A, Portin R, Lindell A, Laihinen A, Bergman J, Haaparanta M, Solin O, Rinne JO. Positron emission tomography shows that impaired frontal lobe functioning in Parkinson's disease is related to dopaminergic hypofunction in the caudate nucleus. Neurosci Lett 2001;311:81-84. [PubMed: 11567783]

Buonamici M, Caccia C, Carpentieri M, Pegrassi L, Rossi AC, Di Chiara G. D-1 receptor supersensitivity in the rat striatum after unilateral 6-hydroxydopamine lesions. Eur J Pharmacol 1986;126:347-348. [PubMed: 3093251]

Burns RS, Chiueh CC, Markey SP, Ebert MH, Jacobowitz DM, Kopin IJ. A primate model of parkinsonism: selective destruction of dopaminergic neurons in the pars compacta of the substantia nigra by N-methyl-4-phenyl-1,2,3,6-tetrahydropyridine. Proc Natl Acad Sci U S A 1983;80:45464550. [PubMed: 6192438]

Calon F, Morissette M, Goulet M, Grondin R, Blanchet PJ, Bedard PJ, Di Paolo T. Chronic D1 and D2 dopaminomimetic treatment of MPTP-denervated monkeys: effects on basal ganglia GABA(A)/ benzodiazepine receptor complex and GABA content. Neurochem Int 1999;35:81-91. [PubMed: 10403433]

Canavan AG, Nixon PD, Passingham RE. Motor learning in monkeys (Macaca fascicularis) with lesions in motor thalamus. Exp Brain Res 1989;77:113-126. [PubMed: 2792254]

Castle M, Aymerich MS, Sanchez-Escobar C, Gonzalo N, Obeso JA, Lanciego JL. Thalamic innervation of the direct and indirect basal ganglia pathways in the rat: Ipsi- and contralateral projections. J Comp Neurol 2005;483:143-153. [PubMed: 15678473]

Cepeda C, Walsh JP, Hull CD, Howard SG, Buchwald NA, Levine MS. Dye-coupling in the neostriatum of the rat: I Modulation by dopamine-depleting lesions. Synapse 1989;4:229-237. [PubMed: 2514464]

Chadha A, Dawson LG, Jenner PG, Duty S. Effect of unilateral 6-hydroxydopamine lesions of the nigrostriatal pathway on GABA(A) receptor subunit gene expression in the rodent basal ganglia and thalamus. Neuroscience 2000;95:119-126. [PubMed: 10619468]

Chen CC, Litvak V, Gilbertson T, Kuhn A, Lu CS, Lee ST, Tsai CH, Tisch S, Limousin P, Hariz M, Brown P. Excessive synchronization of basal ganglia neurons at $20 \mathrm{~Hz}$ slows movement in Parkinson's disease. Exp Neurol 2007;205:214-221. [PubMed: 17335810]

Cho J, Duke D, Manzino L, Sonsalla PK, West MO. Dopamine depletion causes fragmented clustering of neurons in the sensorimotor striatum: evidence of lasting reorganization of corticostriatal input. J Comp Neurol 2002;452:24-37. [PubMed: 12205707]

Courtemanche R, Fujii N, Graybiel AM. Synchronous, focally modulated beta-band oscillations characterize local field potential activity in the striatum of awake behaving monkeys. J Neurosci 2003;23:11741-11752. [PubMed: 14684876]

Creese I, Burt DR, Snyder SH. Dopamine receptor binding enhancement accompanies lesion-induced behavioral supersensitivity. Science 1977;197:596-598. [PubMed: 877576] 
Dagher A, Owen AM, Boecker H, Brooks DJ. The role of the striatum and hippocampus in planning: a PET activation study in Parkinson's disease. Brain 2001;124:1020-1032. [PubMed: 11335704]

Day M, Wang Z, Ding J, An X, Ingham CA, Shering AF, Wokosin D, Ilijic E, Sun Z, Sampson AR, Mugnaini E, Deutch AY, Sesack SR, Arbuthnott GW, Surmeier DJ. Selective elimination of glutamatergic synapses on striatopallidal neurons in Parkinson disease models. Nat Neurosci 2006;9:251-259. [PubMed: 16415865]

DeLong M. Activity of pallidal neurons in the monkey during movement and sleep. Physiologist 1969;12:207.

DeLong MR. Primate models of movement disorders of basal ganglia origin. Trends Neurosci 1990;13:281-285. [PubMed: 1695404]

DeLong MR, Wichmann T. Circuits and circuit disorders of the basal ganglia. Arch Neurol 2007;64:2024. [PubMed: 17210805]

Deuschl G, Raethjen J, Baron R, Lindemann M, Wilms H, Krack P. The pathophysiology of parkinsonian tremor: a review. Journal of Neurology 2000;247(Suppl 5):V33-48. [PubMed: 11081802]

Dogali M, Beric A, Sterio D, Eidelberg D, Fazzini E, Takikawa S, Samelson DR, Devinsky O, Kolodny EH. Anatomic and physiological considerations in pallidotomy for Parkinson's disease. Stereotact Funct Neurosurg 1994;62:53-60. [PubMed: 7631089]

Dogali M, Fazzini E, Kolodny E, Eidelberg D, Sterio D, Devinsky O, Beric A. Stereotactic ventral pallidotomy for Parkinson's disease. Neurology 1995;45:753-761. [PubMed: 7723966]

Dunah AW, Wang Y, Yasuda RP, Kameyama K, Huganir RL, Wolfe BB, Standaert DG. Alterations in subunit expression, composition, and phosphorylation of striatal N-methyl-D-aspartate glutamate receptors in a rat 6-hydroxydopamine model of Parkinson's disease. Mol Pharmacol 2000;57:342352. [PubMed: 10648644]

Eidelberg D. Functional brain networks in movement disorders. CurrOpinion Neurol 1998;11:319-326.

Filion M. Effects of interruption of the nigrostriatal pathway and of dopaminergic agents on the spontaneous activity of globus pallidus neurons in the awake monkey. Brain Res 1979;178:425-441. [PubMed: 116713]

Fogelson N, Williams D, Tijssen M, van Bruggen G, Speelman H, Brown P. Different Functional Loops between Cerebral Cortex and the Subthalmic Area in Parkinson's Disease. CerebrCortex. 2005

Forno LS, DeLanney LE, Irwin I, Langston JW. Similarities and differences between MPTP-induced parkinsonsim and Parkinson's disease. Neuropathologic considerations Advances in Neurology 1993;60:600-608.

Galeffi F, Bianchi L, Bolam JP, Della Corte L. The effect of 6-hydroxydopamine lesions on the release of amino acids in the direct and indirect pathways of the basal ganglia: a dual microdialysis probe analysis. Eur J Neurosci 2003;18:856-868. [PubMed: 12925011]

Gatev P, Darbin O, Wichmann T. Oscillations in the basal ganglia under normal conditions and in movement disorders. Mov Disord 2006;21:1566-1577. [PubMed: 16830313]

Gatev PG, Wichmann T. Changes In Arousal Alter Neuronal Activity In Primate Basal Ganglia. Soc Neurosci Abstr 2003;29

Gatev PG, Wichmann T. State of Arousal and Dopamine Depletion Interact In Studies of Basal Ganglia Activity in Primates. Abstracts, Society for Neuroscience Meeting, Abstract Viewer/Itinerary Planner. 2004Poster 70.14

Gerfen CR, Engber TM, Mahan LC, Susel Z, Chase TN, Monsma FJ Jr, Sibley DR. D1 and D2 dopamine receptor-regulated gene expression of striatonigral and striatopallidal neurons. Science 1990;250:1429-1432. [PubMed: 2147780]

Gill SS, Heywood P. Bilateral subthalamic nucleotomy can be accomplished safely. Movement Disorders 1998;13:201.

Gillies A, Willshaw D, Li Z. Subthalamic-pallidal interactions are critical in determining normal and abnormal functioning of the basal ganglia. Proceedings of the Royal Society of London - Series B, Biological Sciences 2002;269:545-551.

Gnanalingham KK, Robertson RG. Chronic continuous and intermittent L-3,4-dihydroxyphenylalanine treatments differentially affect basal ganglia function in 6-hydroxydopamine lesioned rats--an autoradiographic study using [3H]flunitrazepam. Neuroscience 1993;57:673-681. [PubMed: 8309530] 
Goldberg JA, Boraud T, Maraton S, Haber SN, Vaadia E, Bergman H. Enhanced synchrony among primary motor cortex neurons in the 1-methyl-4-phenyl-1,2,3,6-tetrahydropyridine primate model of Parkinson's disease. J Neurosci 2002;22:4639-4653. [PubMed: 12040070]

Griffiths PD, Sambrook MA, Perry R, Crossman AR. Changes in benzodiazepine and acetylcholine receptors in the globus pallidus in Parkinson's disease. JNeurolSci 1990;100:131-136.

Grossman M, Cooke A, DeVita C, Lee C, Alsop D, Detre J, Gee J, Chen W, Stern MB, Hurtig HI. Grammatical and resource components of sentence processing in Parkinson's disease: an fMRI study. Neurology 2003;60:775-781. [PubMed: 12629232]

Guehl D, Pessiglione M, Francois C, Yelnik J, Hirsch EC, Feger J, Tremblay L. Tremor-related activity of neurons in the 'motor' thalamus: changes in firing rate and pattern in the MPTP vervet model of parkinsonism. Eur J Neurosci 2003;17:2388-2400. [PubMed: 12814370]

Guigoni C, Aubert I, Li Q, Gurevich VV, Benovic JL, Ferry S, Mach U, Stark H, Leriche L, Hakansson K, Bioulac BH, Gross CE, Sokoloff P, Fisone G, Gurevich EV, Bloch B, Bezard E. Pathogenesis of levodopa-induced dyskinesia: focus on D1 and D3 dopamine receptors. Parkinsonism Relat Disord 2005;11(Suppl 1):S25-29. [PubMed: 15885624]

Guigoni C, Doudnikoff E, Li Q, Bloch B, Bezard E. Altered D(1) dopamine receptor trafficking in parkinsonian and dyskinetic non-human primates. Neurobiol Dis 2007;26:452-463. [PubMed: 17350277]

Guridi J, Herrero MT, Luquin R, Guillen J, Obeso JA. Subthalamotomy improves MPTP-induced parkinsonism in monkeys. Stereotact Funct Neurosurg 1994;62:98-102. [PubMed: 7631095]

Guzman JN, Hernandez A, Galarraga E, Tapia D, Laville A, Vergara R, Aceves J, Bargas J. Dopaminergic modulation of axon collaterals interconnecting spiny neurons of the rat striatum. J Neurosci 2003;23:8931-8940. [PubMed: 14523095]

Hamada I, DeLong MR. Excitotoxic acid lesions of the primate subthalamic nucleus result in reduced pallidal neuronal activity during active holding. J Neurophysiol 1992;68:1859-1866. [PubMed: 1479449]

Hammond C, Bergman H, Brown P. Pathological synchronization in Parkinson's disease: networks, models and treatments. Trends Neurosci 2007;30:357-364. [PubMed: 17532060]

Hartmann-von Monakow K, Akert K, Kunzle H. Projections of the precentral motor cortex and other cortical areas of the frontal lobe to the subthalamic nucleus in the monkey. ExpBrain Res 1978;33:395-403.

Hashimoto T, Elder CM, Okun MS, Patrick SK, Vitek JL. Stimulation of the subthalamic nucleus changes the firing pattern of pallidal neurons. J Neurosci 2003;23:1916-1923. [PubMed: 12629196]

Haslinger B, Erhard P, Kampfe N, Boecker H, Rummeny E, Schwaiger M, Conrad B, Ceballos-Baumann AO. Event-related functional magnetic resonance imaging in Parkinson's disease before and after levodopa. Brain 2001;124:558-570. [PubMed: 11222456]

Hassani OK, Mouroux M, Feger J. Increased subthalamic neuronal activity after nigral dopaminergic lesion independent of disinhibition via the globus pallidus. Neuroscience 1996;72:105-115. [PubMed: 8730710]

Heimer G, Bar-Gad I, Goldberg JA, Bergman H. Dopamine replacement therapy reverses abnormal synchronization of pallidal neurons in the 1-methyl-4-phenyl-1,2,3,6-tetrahydropyridine primate model of parkinsonism. J Neurosci 2002;22:7850-7855. [PubMed: 12223537]

Henderson JM, Carpenter K, Cartwright H, Halliday GM. Loss of thalamic intralaminar nuclei in progressive supranuclear palsy and Parkinson's disease: clinical and therapeutic implications. Brain 2000;123(Pt 7):1410-1421. [PubMed: 10869053]

Henderson JM, Schleimer SB, Allbutt H, Dabholkar V, Abela D, Jovic J, Quinlivan M. Behavioural effects of parafascicular thalamic lesions in an animal model of parkinsonism. Behav Brain Res 2005;162:222-232. [PubMed: 15970217]

Hutchison WD, Lozano AM, Davis K, Saint-Cyr JA, Lang AE, Dostrovsky JO. Differential neuronal activity in segments of globus pallidus in Parkinson's disease patients. Neuroreport 1994;5:15331537. [PubMed: 7948856]

Ingham CA, Hood SH, Arbuthnott GW. Spine density on neostriatal neurones changes with 6hydroxydopamine lesions and with age. Brain Res 1989;503:334-338. [PubMed: 2514009] 
Jaeger D, Kita H, Wilson CJ. Surround inhibition among projection neurons is weak or nonexistent in the rat neostriatum. J Neurophysiol 1994;72:2555-2558. [PubMed: 7884483]

Jahanshahi M, Jenkins IH, Brown RG, Marsden CD, Passingham RE, Brooks DJ. Self-initiated versus externally triggered movements. I An investigation using measurement of regional cerebral blood flow with PET and movement-related potentials in normal and Parkinson's disease subjects. Brain 1995;118:913-933. [PubMed: 7655888]

Jenkins IH, Fernandez W, Playford ED, Lees AJ, Frackowiak RS, Passingham RE, Brooks DJ. Impaired activation of the supplementary motor area in Parkinson's disease is reversed when akinesia is treated with apomorphine. Annals of Neurology 1992;32:749-757. [PubMed: 1471865]

Kaneda K, Tachibana Y, Imanishi M, Kita H, Shigemoto R, Nambu A, Takada M. Down-regulation of metabotropic glutamate receptor 1alpha in globus pallidus and substantia nigra of parkinsonian monkeys. Eur J Neurosci 2005;22:3241-3254. [PubMed: 16367790]

Kaneoke Y, Vitek JL. The motor thalamus in the parkinsonian primate: enhanced burst and oscillatory activities. Soc Neurosci Abstr 1995;21:1428.

Katz J, Nielsen KM, Soghomonian JJ. Comparative effects of acute or chronic administration of levodopa to 6-hydroxydopamine-lesioned rats on the expression of glutamic acid decarboxylase in the neostriatum and GABAA receptors subunits in the substantia nigra, pars reticulata. Neuroscience 2005;132:833-842. [PubMed: 15837143]

Kelly RM, Strick PL. Macro-architecture of basal ganglia loops with the cerebral cortex: use of rabies virus to reveal multisynaptic circuits. Prog Brain Res 2004;143:449-459. [PubMed: 14653187]

Kincaid AE, Albin RL, Newman SW, Penney JB, Young AB. 6-hydroxydopamine lesions of the nigrostriatal pathway alter the expression of glutamate decarboxylase messenger RNA in rat globus pallidus projection neurons. Neuroscience 1992;51:705-718. [PubMed: 1488118]

Kish SJ, Rajput A, Gilbert AH, Rozdilsky B, Chang LJ, Shannak K, Hornykiewicz O. GABA is elevated in striatal but not extrastriatal regions in Parkinson's disease: correlation with striatal dopamine loss. AnnNeurol 1986;20:26-31.

Kiss ZH, Davis KD, Tasker RR, Lozano AM, Hu B, Dostrovsky JO. Kinaesthetic neurons in thalamus of humans with and without tremor. Exp Brain Res 2003;150:85-94. [PubMed: 12698220]

Kliem MA, Maidment NT, Ackerson LC, Chen S, Smith Y, Wichmann T. Activation of nigral and pallidal dopamine D1-like receptors modulates basal ganglia outflow in monkeys. J Neurophysiol 2007a; 89:1489-1500.

Kliem MA, Pare JF, Khan ZU, Wichmann T, Smith Y. Comparative ultrastructural analysis of D1 and D5 dopamine receptor distribution in the substantia nigra and globus pallidus of monkeys. IBAGS IX Abstracts 2007b:72.

Kojima J, Yamaji Y, Matsumura M, Nambu A, Inase M, Tokuno H, Takada M, Imai H. Excitotoxic lesions of the pedunculopontine tegmental nucleus produce contralateral hemiparkinsonism in the monkey. Neurosci Lett 1997;226:111-114. [PubMed: 9159502]

Kringelbach ML, Jenkinson N, Owen SL, Aziz TZ. Translational principles of deep brain stimulation. Nat Rev Neurosci 2007;8:623-635. [PubMed: 17637800]

Kuhn AA, Trottenberg T, Kivi A, Kupsch A, Schneider GH, Brown P. The relationship between local field potential and neuronal discharge in the subthalamic nucleus of patients with Parkinson's disease. Exp Neurol 2005;194:212-220. [PubMed: 15899258]

Kuhn AA, Kupsch A, Schneider GH, Brown P. Reduction in subthalamic 8-35 Hz oscillatory activity correlates with clinical improvement in Parkinson's disease. Eur J Neurosci 2006;23:1956-1960. [PubMed: 16623853]

Laitinen LV. Pallidotomy for Parkinson's diesease. NeurosurgClinNAm 1995;6:105-112.

Langston JW, Ballard P, Tetrud JW, Irwin I. Chronic Parkinsonism in humans due to a product of meperidine-analog synthesis. Science 1983;219:979-980. [PubMed: 6823561]

Lapper SR, Bolam JP. Input from the frontalcortex and the parafascicular nucleus to cholinergic interneurons in the dorsal striatum of the rat. Neuroscience 1992;51:533-545. [PubMed: 1488113]

Laprade N, Soghomonian JJ. Gene expression of the GAD67 and GAD65 isoforms of glutamate decarboxylase is differentially altered in subpopulations of striatal neurons in adult rats lesioned with 6-OHDA as neonates. Synapse 1999;33:36-48. [PubMed: 10380849] 
Leblois A, Meissner W, Bioulac B, Gross CE, Hansel D, Boraud T. Late emergence of synchronized oscillatory activity in the pallidum during progressive Parkinsonism. Eur J Neurosci 2007;26:17011713. [PubMed: 17880401]

Lee JI, Shin HJ, Nam DH, Kim JS, Hong SC, Park K, Eoh W, Kim JH, Lee WY. Increased burst firing in substantia nigra pars reticulata neurons and enhanced response to selective D2 agonist in hemiparkinsonian rats after repeated administration of apomorphine. J Korean Med Sci 2001;16:636-642. [PubMed: 11641536]

Lee T, Seeman P, Rajput A, Farley IJ, Hornykiewicz O. Receptor basis for dopaminergic supersensitivity in Parkinson's disease. Nature 1978;273:59-61. [PubMed: 692671]

Levesque M, Parent A. The striatofugal fiber system in primates: a reevaluation of its organization based on single-axon tracing studies. Proc Natl Acad Sci U S A 2005;102:11888-11893. [PubMed: 16087877]

Levy R, Dostrovsky JO, Lang AE, Sime E, Hutchison WD, Lozano AM. Effects of apomorphine on subthalamic nucleus and globus pallidus internus neurons in patients with Parkinson's disease. J Neurophysiol 2001;86:249-260. [PubMed: 11431506]

Levy R, Ashby P, Hutchison WD, Lang AE, Lozano AM, Dostrovsky JO. Dependence of subthalamic nucleus oscillations on movement and dopamine in Parkinson's disease. Brain 2002a;125:11961209. [PubMed: 12023310]

Levy R, Hutchison WD, Lozano AM, Dostrovsky JO. Synchronized neuronal discharge in the basal ganglia of parkinsonian patients is limited to oscillatory activity. J Neurosci 2002b;22:2855-2861. [PubMed: 11923450]

Loucif KC, Wilson CL, Baig R, Lacey MG, Stanford IM. Functional interconnectivity between the globus pallidus and the subthalamic nucleus in the mouse brain slice. J Physiol 2005;567:977-987. [PubMed: 16037086]

Lozano A, Hutchison W, Kiss Z, Tasker R, Davis K, Dostrovsky J. Methods for microelectrode-guided posteroventral pallidotomy. J Neurosurg 1996;84:194-202. [PubMed: 8592221]

Lozano AM, Lang AE, Galvez-Jimenez N, Miyasaki J, Duff J, Hutchinson WD, Dostrovsky JO. Effect of GPi pallidotomy on motor function in Parkinson's disease. Lancet 1995;346:1383-1387. [PubMed: 7475819]

Magill PJ, Bolam JP, Bevan MD. Relationship of activity in the subthalamic nucleus-globus pallidus network to cortical electroencephalogram. J Neurosci 2000;20:820-833. [PubMed: 10632612]

Magill PJ, Bolam JP, Bevan MD. Dopamine regulates the impact of the cerebral cortex on the subthalamic nucleus-globus pallidus network. Neuroscience 2001;106:313-330. [PubMed: 11566503]

Magnin M, Morel A, Jeanmonod D. Single-unit analysis of the pallidum, thalamus and subthalamic nucleus in parkinsonian patients. Neuroscience 2000;96:549-564. [PubMed: 10717435]

Mallet N, Ballion B, Le Moine C, Gonon F. Cortical inputs and GABA interneurons imbalance projection neurons in the striatum of parkinsonian rats. J Neurosci 2006;26:3875-3884. [PubMed: 16597742]

Marie RM, Barre L, Dupuy B, Viader F, Defer G, Baron JC. Relationships between striatal dopamine denervation and frontal executive tests in Parkinson's disease. Neurosci Lett 1999;260:77-80. [PubMed: 10025703]

Marshall JF, Navarrete R, Joyce JN. Decreased striatal D1 binding density following mesotelencephalic 6-hydroxydopamine injections: an autoradiographic analysis. Brain Res 1989;493:247-257. [PubMed: 2527583]

Masimore B, Kakalios J, Redish AD. Measuring fundamental frequencies in local field potentials. [erratum appears in J Neurosci Methods. 2005 Feb 15;141(2):333]. J Neurosci Methods 2004;138:97-105. [PubMed: 15325117]

Mazzone P, Lozano A, Stanzione P, Galati S, Scarnati E, Peppe A, Stefani A. Implantation of human pedunculopontine nucleus: a safe and clinically relevant target in Parkinson's disease. Neuroreport 2005;16:1877-1881. [PubMed: 16272871]

Mazzone P, Insola A, Lozano A, Galati S, Scarnati E, Peppe A, Stanzione P, Stefani A. Peripeduncular and pedunculopontine nuclei: a dispute on a clinically relevant target. Neuroreport 2007;18:14071408. [PubMed: 17762723] 
McIntyre CC, Grill WM, Sherman DL, Thakor NV. Cellular effects of deep brain stimulation: modelbased analysis of activation and inhibition. J Neurophysiol 2004;91:1457-1469. [PubMed: 14668299]

Mena-Segovia J, Bolam JP, Magill PJ. Pedunculopontine nucleus and basal ganglia: distant relatives or part of the same family? Trends Neurosci 2004;27:585-588. [PubMed: 15374668]

Meredith GE, Wouterlood FG. Hippocampal and midline thalamic fibers and terminals in relation to the choline acetyltransferase-immunoreactive neurons in nucleus accumbens of the rat: a light and electron microscopic study. J Comp Neurol 1990;296:204-221. [PubMed: 2358532]

Middleton FA, Strick PL. Basal ganglia and cerebellar loops: motor and cognitive circuits. Brain Res Brain Res Rev 2000;31:236-250. [PubMed: 10719151]

Miller, WC.; DeLong, MR. Altered tonic activity of neurons in the globus pallidus and subthalamic nucleus in the primate MPTP model of parkinsonism. In: Carpenter, MB.; Jayaraman, A., editors. The Basal Ganglia II. New York: Plenum Press; 1987. p. 415-427.

Mitchell IJ, Clarke CE, Boyce S, Robertson RG, Peggs D, Sambrook MA, Crossman AR. Neural mechanisms underlying parkinsonian symptoms based upon regional uptake of 2-deoxyglucose in monkeys exposed to 1-methyl-4-phenyl-1,2,3,6-tetrahydropyridine. Neuroscience 1989;32:213226. [PubMed: 2586750]

Molnar GF, Pilliar A, Lozano AM, Dostrovsky JO. Differences in neuronal firing rates in pallidal and cerebellar receiving areas of thalamus in patients with Parkinson's disease, essential tremor, and pain. J Neurophysiol 2005;93:3094-3101. [PubMed: 15703231]

Moody TD, Bookheimer SY, Vanek Z, Knowlton BJ. An implicit learning task activates medial temporal lobe in patients with Parkinson's disease. Behav Neurosci 2004;118:438-442. [PubMed: 15113271]

Munro-Davies L, Winter J, Aziz TZ, Stein J. Kainate acid lesions of the pedunculopontine region in the normal behaving primate. Mov Disord 2001;16:150-151. [PubMed: 11215577]

Nambu A, Kaneda K, Tokuno H, Takada M. Organization of Corticostriatal Motor Inputs in Monkey Putamen. J Neurophysiol 2002a;88:1830-1842. [PubMed: 12364509]

Nambu A, Tokuno H, Takada M. Functional significance of the cortico-subthalamo-pallidal 'hyperdirect' pathway. Neurosci Res 2002b;43:111-117. [PubMed: 12067746]

Nandi D, Aziz TZ, Giladi N, Winter J, Stein JF. Reversal of akinesia in experimental parkinsonism by GABA antagonist microinjections in the pedunculopontine nucleus. Brain 2002a;125:2418-2430. [PubMed: 12390969]

Nandi D, Liu X, Winter JL, Aziz TZ, Stein JF. Deep brain stimulation of the pedunculopontine region in the normal non-human primate. J Clin Neurosci 2002b;9:170-174. [PubMed: 11922707]

Ni Z, Bouali-Benazzouz R, Gao D, Benabid AL, Benazzouz A. Changes in the firing pattern of globus pallidus neurons after the degeneration of nigrostriatal pathway are mediated by the subthalamic nucleus in the rat. Eur J Neurosci 2000a;12:4338-4344. [PubMed: 11122344]

Ni Z, Bouali-Benazzouz R, Gao D, Benabid AL, Benazzouz A. Intrasubthalamic injection of 6hydroxydopamine induces changes in the firing rate and pattern of subthalamic nucleus neurons in the rat. Synapse 2001a;40:145-153. [PubMed: 11252026]

Ni ZG, Gao DM, Benabid AL, Benazzouz A. Unilateral lesion of the nigrostriatal pathway induces a transient decrease of firing rate with no change in the firing pattern of neurons of the parafascicular nucleus in the rat. Neuroscience 2000b;101:993-999. [PubMed: 11113348]

Ni ZG, Bouali-Benazzouz R, Gao DM, Benabid AL, Benazzouz A. Time-course of changes in firing rates and firing patterns of subthalamic nucleus neuronal activity after 6-OHDA-induced dopamine depletion in rats. Brain Res 2001b;899:142-147. [PubMed: 11311875]

O'Donnell P, Grace AA. Dopaminergic modulation of dye coupling between neurons in the core and shell regions of the nucleus accumbens. J Neurosci 1993;13:3456-3471. [PubMed: 8340817]

Ochi M, Shiozaki S, Kase H. L-DOPA-induced modulation of GABA and glutamate release in substantia nigra pars reticulata in a rodent model of Parkinson's disease. Synapse 2004;52:163-165. [PubMed: 15034922]

Onn SP, Grace AA. Amphetamine withdrawal alters bistable states and cellular coupling in rat prefrontal cortex and nucleus accumbens neurons recorded in vivo. J Neurosci 2000;20:2332-2345. [PubMed: 10704508] 
Pahapill PA, Lozano AM. The pedunculopontine nucleus and Parkinson's disease. Brain 2000;123(Pt 9):1767-1783. [PubMed: 10960043]

Palombo E, Porrino LJ, Bankiewicz KS, Crane AM, Sokoloff L, Kopin IJ. Local cerebral glucose utilization in monkeys with hemiparkinsonism induced by intracarotid infusion of the neurotoxin MPTP. J Neurosci 1990;10:860-869. [PubMed: 2319306]

Pan HS, Penney JB, Young AB. Gamma-aminobutyric acid and benzodiazepine receptor changes induced by unilateral 6-hydroxydopamine lesions of the medial forebrain bundle. JNeurochem 1985;45:1396-1404. [PubMed: 2995585]

Parent A, Charara A, Pinault D. Single striatofugal axons arborizing in both pallidal segments and in the substantia nigra in primates. Brain Res 1995;698:280-284. [PubMed: 8581498]

Pedneault S, Soghomonian JJ. Glutamate decarboxylase (GAD65) mRNA levels in the striatum and pallidum of MPTP-treated monkeys. Brain Res Mol Brain Res 1994;25:351-354. [PubMed: 7808234]

Pessiglione M, Guehl D, Rolland AS, Francois C, Hirsch EC, Feger J, Tremblay L. Thalamic neuronal activity in dopamine-depleted primates: evidence for a loss of functional segregation within basal ganglia circuits. J Neurosci 2005;25:1523-1531. [PubMed: 15703406]

Peters S, Suchan B, Rusin J, Daum I, Koster O, Przuntek H, Muller T, Schmid G. Apomorphine reduces BOLD signal in fMRI during voluntary movement in Parkinsonian patients. Neuroreport 2003;14:809-812. [PubMed: 12858037]

Plaha P, Gill SS. Bilateral deep brain stimulation of the pedunculopontine nucleus for Parkinson's disease. Neuroreport 2005;16:1883-1887. [PubMed: 16272872]

Playford ED, Jenkins IH, Passingham RE, Nutt J, Frackowiak RS, Brooks DJ. Impaired mesial frontal and putamen activation in Parkinson's disease: a positron emission tomography study. Annals of Neurology 1992;32:151-161. [PubMed: 1510355]

Plenz D, Kitai S. A basal ganglia pacemaker formed by the subthalamic nucleus and external globus pallidus. Nature 1999;400:677-682. [PubMed: 10458164]

Priori A, Foffani G, Pesenti A, Tamma F, Bianchi AM, Pellegrini M, Locatelli M, Moxon KA, Villani RM. Rhythm-specific pharmacological modulation of subthalamic activity in Parkinson's disease. Exp Neurol 2004;189:369-379. [PubMed: 15380487]

Prokopenko VF, Pawlak AP, West MO. Fluctuations in somatosensory responsiveness and baseline firing rates of neurons in the lateral striatum of freely moving rats: effects of intranigral apomorphine. Neuroscience 2004;125:1077-1082. [PubMed: 15120867]

Raeva S, Vainberg N, Dubinin V. Analysis of spontaneous activity patterns of human thalamic ventrolateral neurons and their modifications due to functional brain changes. Neuroscience 1999;88:365-376. [PubMed: 10197760]

Raz A, Feingold A, Zelanskaya V, Vaadia E, Bergman H. Neuronal synchronization of tonically active neurons in the striatum of normal and parkinsonian primates. J Neurophysiol 1996;76:2083-2088. [PubMed: 8890317]

Raz A, Vaadia E, Bergman H. Firing patterns and correlations of spontaneous discharge of pallidal neurons in the normal and the tremulous 1-methyl-4-phenyl-1,2,3,6-tetrahydropyridine vervet model of parkinsonism. J Neurosci 2000;20:8559-8571. [PubMed: 11069964]

Raz A, Frechter-Mazar V, Feingold A, Abeles M, Vaadia E, Bergman H. Activity of pallidal and striatal tonically active neurons is correlated in mptp-treated monkeys but not in normal monkeys. $\mathrm{J}$ Neurosci 2001;21:RC128. [PubMed: 11157099]

Rivlin-Etzion M, Marmor O, Heimer G, Raz A, Nini A, Bergman H. Basal ganglia oscillations and pathophysiology of movement disorders. Curr Opin Neurobiol 2006;16:629-637. [PubMed: 17084615]

Rivlin-Etzion M, Marmor O, Saban G, Rosin B, Haber SN, Vaadia E, Prut Y, Bergman H. Low-pass filter properties of basal ganglia cortical muscle loops in the normal and MPTP primate model of parkinsonism. J Neurosci 2008;28:633-649. [PubMed: 18199764]

Robertson RG, Clarke CA, Boyce S, Sambrook MA, Crossman AR. The role of striatopallidal neurones utilizing gamma-aminobutyric acid in the pathophysiology of MPTP-induced parkinsonism in the primate: evidence from [3H]flunitrazepam autoradiography. Brain Res 1990;531:95-104.

[PubMed: 2289139] 
Robertson RG, Graham WC, Sambrook MA, Crossman AR. Further investigations into the pathophysiology of MPTP-induced parkinsonism in the primate: an intracerebral microdialysis study of gamma-aminobutyric acid in the lateral segment of the globus pallidus. Brain Res 1991;563:278-280. [PubMed: 1786541]

Rolland AS, Herrero MT, Garcia-Martinez V, Ruberg M, Hirsch EC, Francois C. Metabolic activity of cerebellar and basal ganglia-thalamic neurons is reduced in parkinsonism. Brain 2007;130:265275. [PubMed: 17148469]

Rothblat DS, Schneider JS. Alterations in pallidal neuronal responses to peripheral sensory and striatal stimulation in symptomatic and recovered parkinsonian cats. Brain Res 1995;705:1-14. [PubMed: 8821727]

Salin P, Manrique C, Forni C, Kerkerian-Le Goff L. High-frequency stimulation of the subthalamic nucleus selectively reverses dopamine denervation-induced cellular defects in the output structures of the basal ganglia in the rat. J Neurosci 2002;22:5137-5148. [PubMed: 12077209]

Samadi P, Gregoire L, Morissette M, Calon F, Tahar AH, Belanger N, Dridi M, Bedard PJ, Di Paolo T. Basal ganglia group II metabotropic glutamate receptors specific binding in non-human primate model of L-Dopa-induced dyskinesias. Neuropharmacology. 2007

Samuel M, Ceballos-Baumann AO, Blin J, Uema T, Boecker H, Passingham RE, Brooks DJ. Evidence for lateral premotor and parietal overactivity in Parkinson's disease during sequential and bimanual movements. A PET study. Brain 1997;120:963-976. [PubMed: 9217681]

Sarnthein J, Jeanmonod D. High thalamocortical theta coherence in patients with Parkinson's disease. J Neurosci 2007;27:124-131. [PubMed: 17202479]

Schneider JS, Rothblat DS. Alterations in intralaminar and motor thalamic physiology following nigrostriatal dopamine depletion. Brain Res 1996;742:25-33. [PubMed: 9117401]

Schneider JS, Wade TV. Experimental parkinsonism is associated with increased pallidal GAD gene expression and is reversed by site-directed antisense gene therapy. Movement Disorders 2003;18:32-40. [PubMed: 12518298]

Schwartzman RJ, Alexander GM. Spinal cord metabolism of the 1-methyl-4-phenyl-1,2,3, 6tetrahydropyridine-treated monkey. Brain Res 1985a;337:263-268. [PubMed: 3875382]

Schwartzman RJ, Alexander GM. Changes in the local cerebral metabolic rate for glucose in the 1methyl-4-phenyl-1,2,3,6-tetrahydropyridine (MPTP) primate model of Parkinson's disease. Brain Res 1985b;358:137-143. [PubMed: 3878182]

Sharott A, Magill PJ, Bolam JP, Brown P. Directional analysis of coherent oscillatory field potentials in the cerebral cortex and basal ganglia of the rat. J Physiol 2005;562:951-963. [PubMed: 15550466]

Shen KZ, Johnson SW. Presynaptic dopamine D2 and muscarine M3 receptors inhibit excitatory and inhibitory transmission to rat subthalamic neurones in vitro. J Physiol (Lond) 2000;525(Pt 2):331341. [PubMed: 10835037]

Shen KZ, Johnson SW. Dopamine depletion alters responses to glutamate and GABA in the rat subthalamic nucleus. Neuroreport 2005;16:171-174. [PubMed: 15671871]

Shih LC, Tarsy D. Deep brain stimulation for the treatment of atypical parkinsonism. Mov Disord 2007;22:2149-2155. [PubMed: 17659638]

Sidibe M, Smith Y. Differential synaptic innervation of striatofugal neurones projecting to the internal or external segments of the globus pallidus by thalamic afferents in the squirrel monkey. J Comp Neurol 1996;365:445-465. [PubMed: 8822181]

Sidibe M, Smith Y. Thalamic inputs to striatal interneurons in monkeys: synaptic organization and colocalization of calcium binding proteins. Neuroscience 1999;89:1189-1208. [PubMed: 10362307]

Silberstein P, Pogosyan A, Kuhn AA, Hotton G, Tisch S, Kupsch A, Dowsey-Limousin P, Hariz MI, Brown P. Cortico-cortical coupling in Parkinson's disease and its modulation by therapy. Brain 2005;128:1277-1291. [PubMed: 15774503]

Simola N, Morelli M, Carta AR. The 6-hydroxydopamine model of Parkinson's disease. Neurotoxicity Research 2007;11:151-167. [PubMed: 17449457]

Soares J, Kliem MA, Betarbet R, Greenamyre JT, Yamamoto B, Wichmann T. Role of external pallidal segment in primate parkinsonism: comparison of the effects of MPTP-induced parkinsonism and lesions of the external pallidal segment. J Neurosci 2004;24:6417-6426. [PubMed: 15269251] 
Soghomonian JJ, Pedneault S, Audet G, Parent A. Increased glutamate decarboxylase mRNA levels in the striatum and pallidum of MPTP-treated primates. J Neurosci 1994;14:6256-6265. [PubMed: 7931578]

Soghomonian JJ, Laprade N. Glutamate decarboxylase (GAD67 and GAD65) gene expression is increased in a subpopulation of neurons in the putamen of Parkinsonian monkeys. Synapse 1997;27:122-132. [PubMed: 9266773]

Stanford IM. Independent neuronal oscillators of the rat globus pallidus. J Neurophysiol 2003;89:17131717. [PubMed: 12626634]

Stefani A, Lozano AM, Peppe A, Stanzione P, Galati S, Tropepi D, Pierantozzi M, Brusa L, Scarnati E, Mazzone P. Bilateral deep brain stimulation of the pedunculopontine and subthalamic nuclei in severe Parkinson's disease. Brain 2007;130:1596-1607. [PubMed: 17251240]

Surmeier DJ, Song WJ, Yan Z. Coordinated expression of dopamine receptors in neostriatal medium spiny neurons. J Neurosci 1996;16:6579-6591. [PubMed: 8815934]

Taha JM, Favre J, Baumann TK, Burchiel KJ. Tremor control after pallidotomy in patients with Parkinson's disease: correlation with microrecording findings. J Neurosurg 1997;86:642-647. [PubMed: 9120628]

Terman D, Rubin JE, Yew AC, Wilson CJ. Activity patterns in a model for the subthalamopallidal network of the basal ganglia. J Neurosci 2002;22:2963-2976. [PubMed: 11923461]

Testa CM, Friberg IK, Weiss SW, Standaert DG. Immunohistochemical localization of metabotropic glutamate receptors mGluR1a and mGluR2/3 in the rat basal ganglia. J Comp Neurol 1998;390:519. [PubMed: 9456172]

Thobois S, Dominey P, Decety J, Pollak P, Gregoire MC, Broussolle E. Overactivation of primary motor cortex is asymmetrical in hemiparkinsonian patients. Neuroreport 2000;11:785-789. [PubMed: 10757520]

Timmermann L, Wojtecki L, Gross J, Lehrke R, Voges J, Maarouf M, Treuer H, Sturm V, Schnitzler A. Ten-Hertz stimulation of subthalamic nucleus deteriorates motor symptoms in Parkinson's disease. Movement Disorders 2004;19:1328-1333. [PubMed: 15389990]

Tofighy A, Abbott A, Centonze D, Cooper AJ, Noor E, Pearce SM, Puntis M, Stanford IM, Wigmore MA, Lacey MG. Excitation by dopamine of rat subthalamic nucleus neurones in vitro-a direct action with unconventional pharmacology. Neuroscience 2003;116:157-166. [PubMed: 12535949]

Tseng KY, Riquelme LA, Belforte JE, Pazo JH, Murer MG. Substantia nigra pars reticulata units in 6hydroxydopamine-lesioned rats: responses to striatal D2 dopamine receptor stimulation and subthalamic lesions. Eur J Neurosci 2000;12:247-256. [PubMed: 10651879]

Turner RS, Grafton ST, McIntosh AR, DeLong MR, Hoffman JM. The functional anatomy of parkinsonian bradykinesia. Neuroimage 2003;19:163-179. [PubMed: 12781736]

Ungerstedt U. 6-Hydroxy-dopamine induced degeneration of central monoamine neurons. Eur J Pharmacol 1968;5:107-110. [PubMed: 5718510]

Ungerstedt U, Arbuthnott GW. Quantitative recording of rotational behavior in rats after 6-hydroxydopamine lesions of the nigrostriatal dopamine system. Brain Res 1970;24:485-493. [PubMed: 5494536]

Urbain N, Gervasoni D, Souliere F, Lobo L, Rentero N, Windels F, Astier B, Savasta M, Fort P, Renaud B, Luppi PH, Chouvet G. Unrelated course of subthalamic nucleus and globus pallidus neuronal activities across vigilance states in the rat. Eur J Neurosci 2000;12:3361-3374. [PubMed: 10998119]

Vila M, Perier C, Feger J, Yelnik J, Faucheux B, Ruberg M, Raisman-Vozari R, Agid Y, Hirsch EC. Evolution of changes in neuronal activity in the subthalamic nucleus of rats with unilateral lesion of the substantia nigra assessed by metabolic and electrophysiological measurements. Eur J Neurosci 2000;12:337-344. [PubMed: 10651888]

Villalba RM, Verreault M, Smith Y. Spine loss in the striatum of MPTP-treated monkeys. A correlation with the degree of striatal dopaminergic denervation. Society for Neuroscience 2006:431.415.

Vitek JL, Ashe J, Kaneoke Y. Spontaneous neuronal activity in the motor thalamus: alteration in pattern and rate in parkinsonism. Soc Neurosci Abstr 1994;20:561. 
Vitek JL, Bakay RA, Freeman A, Evatt M, Green J, McDonald W, Haber M, Barnhart H, Wahlay N, Triche S, Mewes K, Chockkan V, Zhang JY, DeLong MR. Randomized trial of pallidotomy versus medical therapy for Parkinson's disease. Ann Neurol 2003;53:558-569. [PubMed: 12730989]

Wang SY, Aziz TZ, Stein JF, Liu X. Time-frequency analysis of transient neuromuscular events: dynamic changes in activity of the subthalamic nucleus and forearm muscles related to the intermittent resting tremor. J Neurosci Methods 2005;145:151-158. [PubMed: 15922033]

Wang Z, Kai L, Day M, Ronesi J, Yin HH, Ding J, Tkatch T, Lovinger DM, Surmeier DJ. Dopaminergic control of corticostriatal long-term synaptic depression in medium spiny neurons is mediated by cholinergic interneurons. Neuron 2006;50:443-452. [PubMed: 16675398]

Watts RL, Mandir AS. The role of motor cortex in the pathophysiology of voluntary movement deficits associated with parkinsonism. Neurol Clin 1992;10:451-469. [PubMed: 1584184]

Weinberger M, Mahant N, Hutchison WD, Lozano AM, Moro E, Hodaie M, Lang AE, Dostrovsky JO. Beta oscillatory activity in the subthalamic nucleus and its relation to dopaminergic response in Parkinson's disease. J Neurophysiol 2006;96:3248-3256. [PubMed: 17005611]

Wichmann, T.; DeLong, MR. Pathophysiology of parkinsonian motor abnormalities. In: Narabayashi, H.; Nagatsu, T.; Yanagisawa, N.; Mizuno, Y., editors. Advances in Neurology. 60. New York: Raven Press, Ltd; 1993. p. 53-61.

Wichmann T, Bergman H, Starr PA, Subramanian T, Watts RL, DeLong MR. Comparison of MPTPinduced changes in spontaneous neuronal discharge in the internal pallidal segment and in the substantia nigra pars reticulata in primates. Exp Brain Res 1999;125:397-409. [PubMed: 10323285]

Wichmann T, Gatev PG, Kliem MA. Neuronal discharge in the basal ganglia is correlated with EEG in normal and parkinsonina primates. Movement Disorders (Abstract Volume) 2002;17(Suppl 5):S155.

Wichmann T, Soares J. Neuronal firing before and after burst discharges in the monkey Basal Ganglia is predictably patterned in the normal state and altered in parkinsonism. J Neurophysiol 2006;95:2120-2133. [PubMed: 16371459]

Wilson CL, Puntis M, Lacey MG. Overwhelmingly asynchronous firing of rat subthalamic nucleus neurones in brain slices provides little evidence for intrinsic interconnectivity. Neuroscience 2004;123:187-200. [PubMed: 14667453]

Windels F, Carcenac C, Poupard A, Savasta M. Pallidal origin of GABA release within the substantia nigra pars reticulata during high-frequency stimulation of the subthalamic nucleus. J Neurosci 2005;25:5079-5086. [PubMed: 15901790]

Wingeier B, Tcheng T, Koop MM, Hill BC, Heit G, Bronte-Stewart HM. Intra-operative STN DBS attenuates the prominent beta rhythm in the STN in Parkinson's disease. Exp Neurol 2006;197:244251. [PubMed: 16289053]

$\mathrm{Wu}$ Y, Richard S, Parent A. The organization of the striatal output system: a single-cell juxtacellular labeling study in the rat. Neurosci Res 2000;38:49-62. [PubMed: 10997578]

Xuereb JH, Perry RH, Candy JM, Perry EK, Marshall E, Bonham JR. Nerve cell loss in the thalamus in Alzheimer's disease and Parkinson's disease. Brain 1991;114:1363-1379. [PubMed: 2065255]

Zaja-Milatovic S, Milatovic D, Schantz AM, Zhang J, Montine KS, Samii A, Deutch AY, Montine TJ. Dendritic degeneration in neostriatal medium spiny neurons in Parkinson disease. Neurology 2005;64:545-547. [PubMed: 15699393]

Zhu Z, Bartol M, Shen K, Johnson SW. Excitatory effects of dopamine on subthalamic nucleus neurons: in vitro study of rats pretreated with 6-hydroxydopamine and levodopa. Brain Res 2002a;945:3140. [PubMed: 12113949]

Zhu ZT, Shen KZ, Johnson SW. Pharmacological identification of inward current evoked by dopamine in rat subthalamic neurons in vitro. Neuropharmacology 2002b;42:772-781. [PubMed: 12015203]

Zirh TA, Lenz FA, Reich SG, Dougherty PM. Patterns of bursting occurring in thalamic cells during parkinsonian tremor. Neuroscience 1998;83:107-121. [PubMed: 9466402]

Zrinzo L, Zrinzo L, Hariz M. The peripeduncular nucleus: a novel target for deep brain stimulation? Neuroreport 2007a;18:1631-1632. [PubMed: 17948606] author reply 1632-1633

Zrinzo L, Zrinzo LV, Hariz M. The pedunculopontine and peripeduncular nuclei: a tale of two structures. Brain 2007b;130:e73. [PubMed: 17525137] author reply e74 
Normal

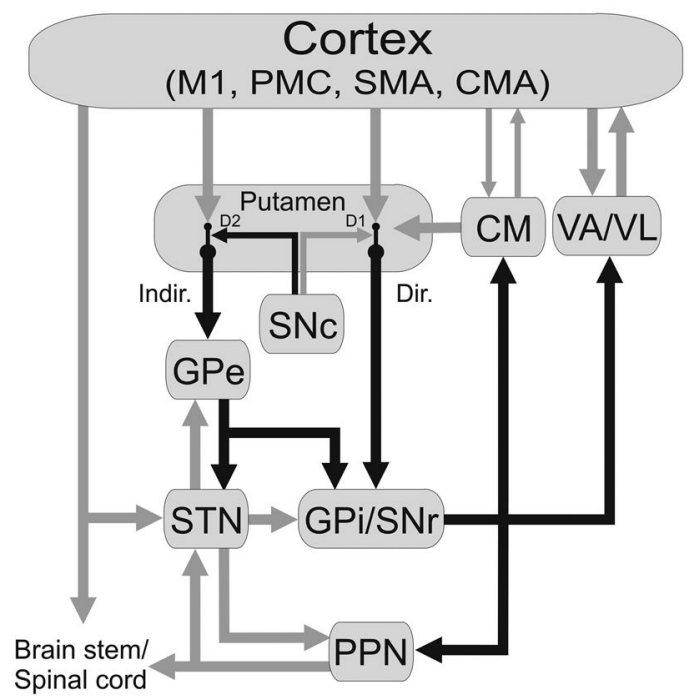

Parkinsonism

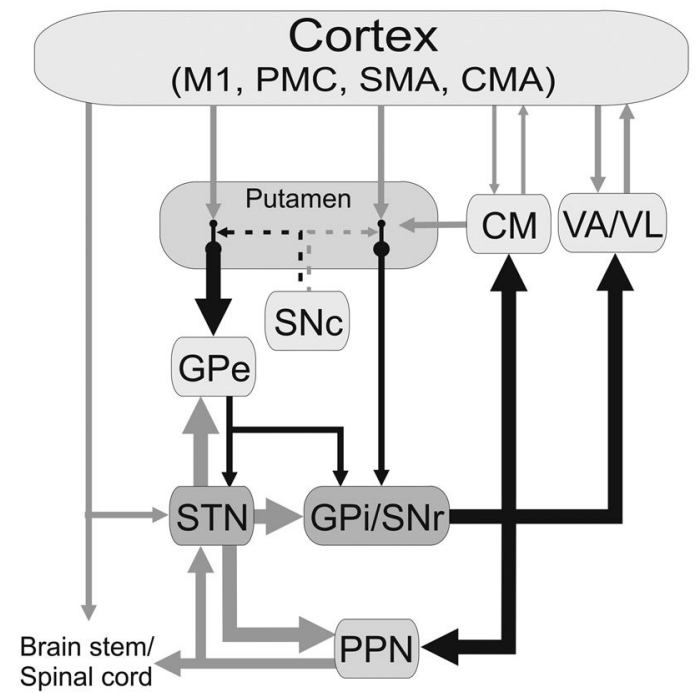

Figure 1.

Parkinsonism-related changes in overall activity ('rate model') in the basal gangliathalamocortical motor circuit. Black arrows indicate inhibitory connections; gray arrows indicate excitatory connections. The thickness of the arrows corresponds to their presumed activity. Abbreviations: CM, centromedian nucleus of thalamus; CMA, cingulate motor area; Dir., direct pathway; D1, D2, dopamine receptor subtypes; GPe, external segment of the globus pallidus; GPi, internal segment of the globus pallidus; Indir., indirect pathway; M1, primary motor cortex; Pf, parafascicular nucleus of the thalamus; PMC, premotor cortex; PPN, pedunculopontine nucleus; SMA, supplementary motor area; SNc, substantia nigra pars compacta; SNr, substantia nigra pars reticulata; STN, subthalamic nucleus; VA, ventral anterior nucleus of thalamus; VL, ventrolateral nucleus of thalamus. 


\section{Normal}
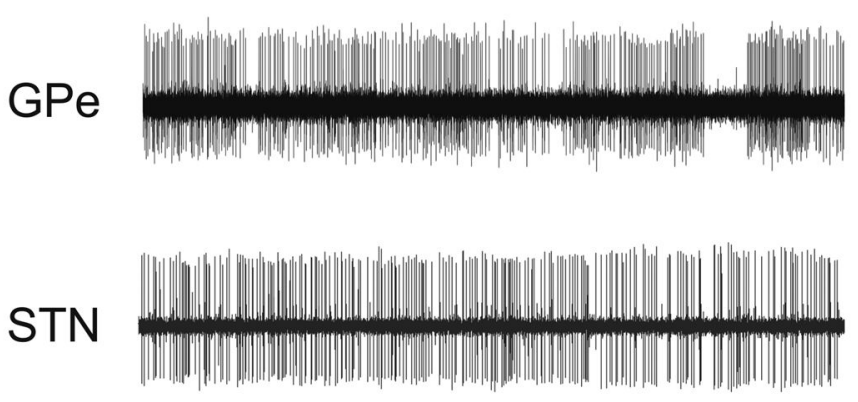

GPi

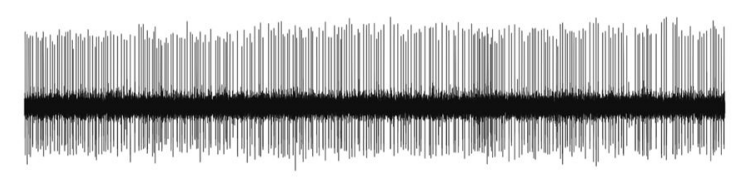

\section{Parkinsonism}

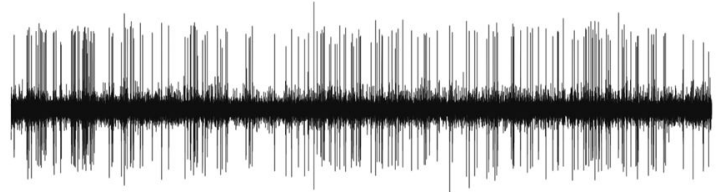

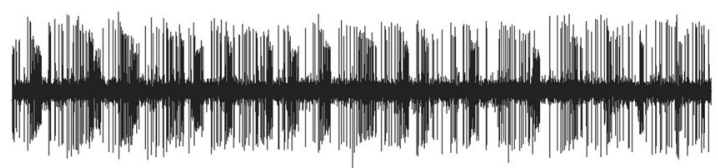

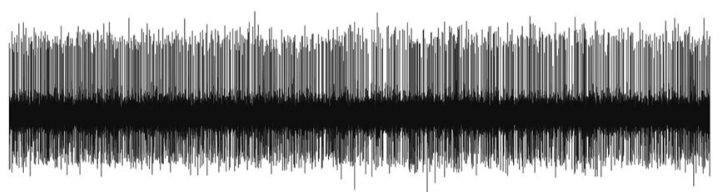

Figure 2.

Changes in the activity of single cells in GPe, STN or GPi of MPTP-treated monkeys. Shown are examples of separate neurons, recorded with standard extracellular electrophysiologic recording methods in normal and parkinsonian animals. Each data segment is 5 seconds in duration. 

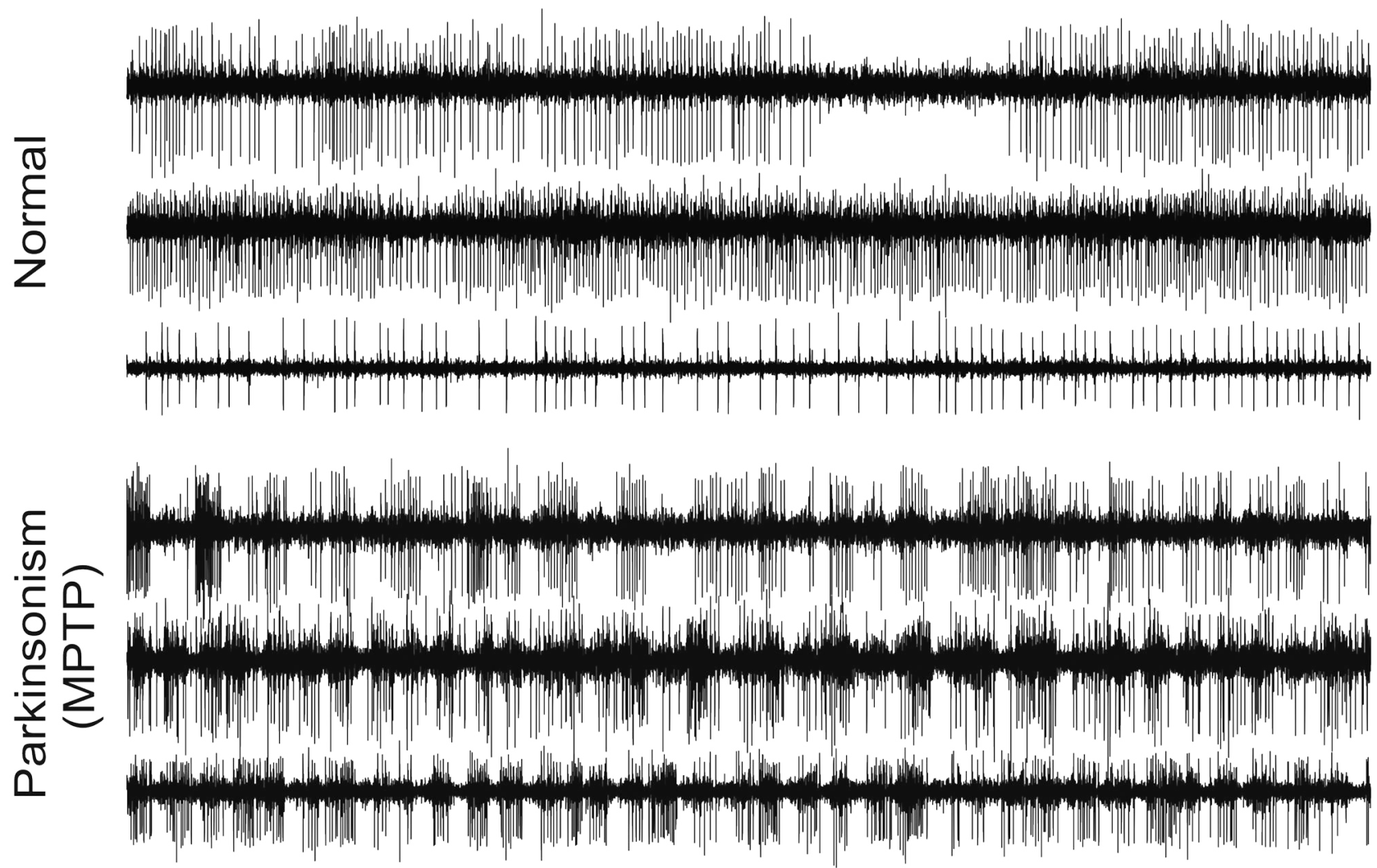

\section{$0.5 \mathrm{~s}$}

Figure 3.

Simultaneous independent extracellular electrophysiologic recordings of the activity of several neurons in the globus pallidus in a normal (A) and a parkinsonian monkey (B). Traces represent 2.5 s-long example of neuronal activity. In the normal state (A.), the activity of neighboring neurons was not correlated. In the parkinsonian state (B.), however, episodes of synchronous, episodic bursting developed. For abbreviations, see text. The figure is a reproduction of figure 3 in (Bergman et al., 1998a), with permission. 